\title{
Electronic Effects in PCP-Pincer Ru(II)-Based Hydrogen Transfer Catalysis
}

\author{
Marcella Gagliardo, Preston A. Chase, Sander Brouwer, Gerard P. M. van Klink, and \\ Gerard van Koten*

\begin{abstract}
Faculty of Science, Organic Chemistry and Catalysis, Utrecht University, Padualaan 8, $3584 \mathrm{CH}$ Utrecht, The Netherlands
\end{abstract}

Received September 25, 2006

\begin{abstract}
The synthesis and characterization of novel cyclometalated ruthenium(II) complexes $\left[\mathrm{RuCl}\left(\mathrm{PCP}^{\mathrm{OMe}}\right)\right.$ $\left.\left(\mathrm{PPh}_{3}\right)\right]$ and $\left[\mathrm{RuCl}\left(\mathrm{PCP}^{\mathrm{CF} 3}\right)\left(\mathrm{PPh}_{3}\right)\right]$ containing monoanionic, tridentate coordinating PCP-pincer ligands $\left[\mathrm{C}_{6} \mathrm{H}_{3}\left\{\mathrm{CH}_{2} \mathrm{P}\left(p-\mathrm{MeOC}_{6} \mathrm{H}_{4}\right)_{2}\right\}_{2}-2,6\right]^{-}(\mathrm{PCPOMe})$ and $\left[\mathrm{C}_{6} \mathrm{H}_{3}\left\{\mathrm{CH}_{2} \mathrm{P}\left(p-\mathrm{CF}_{3} \mathrm{C}_{6} \mathrm{H}_{4}\right)_{2}\right\}_{2}-2,6\right]^{-}\left(\mathrm{PCPCF}^{\mathrm{C} 3}\right)$ are reported. These compounds have been tested as catalyst precursors in the hydrogen transfer reaction of cyclohexanone to cyclohexanol in 2-propanol using $\mathrm{NaOH}$ as a base. The initial rate of the hydrogen transfer reaction appeared to depend on the electronic character of the $\mathrm{Ar}_{2} \mathrm{P}-$ groups of the PCP-pincer ligand. Among the catalyst precursors studied, the complex $\left[\mathrm{RuCl}\left(\mathrm{PCP}{ }^{\mathrm{CF}}\right)\left(\mathrm{PPh}_{3}\right)\right]$ was found to exhibit the highest activity and the initial TOF exceeded that observed for the $\mathrm{Ph}_{2} \mathrm{P}$ analogue $\left[\mathrm{RuCl}\left(\mathrm{PCP}^{\mathrm{Ph}}\right)\right.$ $\left.\left(\mathrm{PPh}_{3}\right)\right]$. Most importantly, catalysis performed with $\left[\mathrm{RuCl}\left(\mathrm{PCP}{ }^{\mathrm{CF}}\right)\left(\mathrm{PPh}_{3}\right)\right]$ does not require pretreatment of the precursor in the absence of substrate. Conversely, a different catalytic profile and a low activity were observed when either the electron-poor $\left[\mathrm{RuCl}\left\{\mathrm{C}_{6} \mathrm{H}_{3}\left(\mathrm{CH}_{2} \mathrm{P}\left(\mathrm{C}_{6} \mathrm{~F}_{5}\right)_{2}\right)_{2}-2,6\right\}\left(\mathrm{PPh}_{3}\right)\right]\left(\left[\mathrm{RuCl}\left(\mathrm{PCP}^{\mathrm{F} 20}\right)\right.\right.$ $\left.\left(\mathrm{PPh}_{3}\right)\right]$ ) complex or its triflate analogue was used as catalyst precursors. NMR studies and ESI-MS measurements provided information concerning the catalytically active species formed during the pretreatment of the precursor complexes. The results indicate that during the pretreatment period a monoanionic, monohydride ruthenium(II) species, $\mathrm{Na}\left[\mathrm{Ru}(\mathrm{H})\left(\mathrm{PCP}{ }^{i \mathrm{Pr}}\right)(\mathrm{O} i \mathrm{Pr})\left(\mathrm{PPh}_{3}\right)\right]$, is selectively formed. The latter hydride complex was also obtained via an independent synthetic route. On the basis of both the present results and those previously reported in literature, a mechanism is proposed.
\end{abstract}

\section{Introduction}

Hydrogen transfer catalysis is an attractive protocol for the reduction of ketones to alcohols in both academic and industrial research. ${ }^{1}$ The use of a hydrogen donor (e.g., 2-propanol) instead of using molecular dihydrogen gas or hazardous reducing agents (e.g., $\mathrm{NaBH}_{4}$ and $\mathrm{LiAlH}_{4}$ ) has a potential advantage in terms of mild reaction conditions and excellent regioselectivity. ${ }^{1}$

Many metal complexes of $\mathrm{Rh}, \mathrm{Ir}$, and $\mathrm{Ru}$ have been found to be active catalysts in (a)symmetric hydrogen transfer reactions of polar groups (e.g., ketones and imines). ${ }^{1}$ In recent years a number of studies appeared on the successful use of cyclometalated ruthenium(II) complexes containing either tridentate, cyclometalated PCP-,${ }^{2} \mathrm{NCN}-,{ }^{2 a}$ and $\mathrm{CNN}$-pincer, ${ }^{3}$ or bidentate $\mathrm{PC}^{-}{ }^{4}$ and NC-ligands ${ }^{5}$ as catalyst precursors in hydrogen transfer reactions. The great interest in the use of $E, C, E$-pincer ligands $(E=\mathrm{N}, \mathrm{P})$ arises from the remarkable stability of the

* Author to whom correspondence should be addressed. E-mail: g.vankoten@chem.uu.nl. Fax: +31-30-252-3615. Tel: +31-30-253-3120.

(1) (a) Zassinovich, G.; Mestroni, G.; Gladiali, S. Chem. Rev. 1992, 92, 1051. (b) Noyori, N.; Hashiguchi, S. Acc. Chem. Res. 1997, 30, 97. (c) Bäckvall, J. E. J. Organomet. Chem. 2002, 652, 105 (d) Zhang, X.; Tang, W. Chem. Rev. 2003, 103, 3029.

(2) (a) Dani, P.; Karlen, T.; Gossage, R. A.; Gladiali, S.; van Koten, G. Angew. Chem., Int. Ed. 2000, 39, 743. (b) Amoroso, D.; Jabri, A.; Yap, G. P. A.; Gusev, D. G.; dos Santos, E. N.; Fogg, D. E. Organometallics 2004, 23, 4047. (c) Medici, S.; Gagliardo, M.; Chase, P. A.; Williams, S. B.; Gladiali, S.; Lutz, M.; Spek, A. L.; van Klink, G. P. M.; van Koten, G. Helv. Chim. Acta 2005, 88, 694.

(3) (a) Baratta, W. L.; Chelucci, G.; Gladiali, S.; Siega, K.; Toniutti, M.; Zanette, M.; Zangrando, E.; Rigo, P. Angew. Chem., Int. Ed. 2005, 44, 6214.

(4) Baratta, W.; Da Ros, P.; Del Zotto, A.; Sechi, A.; Zangrando, E.; Rigo, P. Angew. Chem., Int. Ed. 2004, 43, 3584. corresponding metal complexes and the possibility to modulate the reactivity of the metal center by fine-tuning and control of the electronic and steric properties of the ligand framework (e.g., via introduction of an appropriate para-substituent in the pincer's aryl ring or by variation of the substituents at the $E$ donor atoms). ${ }^{6}$

Van Koten and co-workers detailed the application of achiral ${ }^{2 a}$ $\left[\mathrm{RuX}\left(\mathrm{PCP}{ }^{\mathrm{Ph}}\right)\left(\mathrm{PPh}_{3}\right)\right](\mathrm{X}=\mathrm{Cl}(\mathbf{1 a})$, OTf (1b), Scheme 1) and chiral $^{2 \mathrm{c}}$ (Scheme 1) $(S, S)-\left[\mathrm{RuCl}\left(\mathrm{PCP}^{t \mathrm{Bu}}, \mathrm{Ph}\right)\left(\mathrm{PPh}_{3}\right)\right]$ and $(S, S)$ $\left[\mathrm{RuCl}\left(\mathrm{PCP} \mathrm{P}^{i \mathrm{Pr}} \mathrm{Ph}\right)\left(\mathrm{PPh}_{3}\right)\right]$ as catalyst precursors in the reduction of aryl and diaryl ketones targeted as precursors to pharmaceutically desirable benzhydrols. Initial TOF up to $2.5 \times 10^{4} \mathrm{~h}^{-1}$ could be reached. ${ }^{2 a}$ Recent studies reported on the synthesis of novel, cyclometalated PCP-pincer and PC-ligand Ru(II) compounds, $\left[\mathrm{RuCl}\left(\mathrm{PCP}^{\mathrm{Cy}}\right)\left(\mathrm{PPh}_{3}\right)\right](2)$ containing the bulky, electronrich, tridentate coordinating $\left[\mathrm{C}_{6} \mathrm{H}_{3}\left(\mathrm{CH}_{2} \mathrm{PCy}_{2}\right)_{2}-2,6\right]^{-}$pincer ligand $^{2 \mathrm{~b}}$ and $[\mathrm{RuCl}(\mathrm{CO})(\mathrm{PC})(\mathrm{ampy})]\left(\mathrm{PC}=\left[\left(2-\mathrm{CH}_{2}-6-\mathrm{MeC}_{6} \mathrm{H}_{3}\right)-\right.\right.$ $\left.\mathrm{PPh}_{2}\right]^{-}$; ampy $=2$-(aminomethyl)pyridine) ${ }^{4}$ Results obtained by van Koten, ${ }^{2 \mathrm{a}, \mathrm{c}}$ Fogg, ${ }^{2 \mathrm{~b}}$ and $\mathrm{Baratta}^{4}$ highlighted that the PCP$\mathrm{Ru}$ and $\mathrm{PC}-\mathrm{Ru}$ structural units are preserved during the catalytic cycle. Apparently, the presence of a unique, robust $\mathrm{Ru}-\mathrm{C}$ $\sigma$-bond between the ruthenium(II) center and the $E, C, E$-pincer

(5) (a) Sortais, J. B.; Ritleng, V.; Voelklin, A.; Holuigue, A.; Smail, H.; Barloy, L.; Sirlin, C.; Verzijl, G. K. M.; Boogers, J. A. F.; de Vries, A. H. M.; de Vries, J. G.; Pfeffer, M. Org. Lett. 2005, 7, 1247. (b) Sortais, J. B.; Barloy, L.; Sirlin, C.; de Vries, A. H. M.; de Vries, J. G.; Pfeffer, M. Pure Appl. Chem. 2006, 78, 457.

(6) For review on pincer complexes see: (a) Albrecht, M.; van Koten, G. Angew. Chem., Int. Ed. 2001, 40, 3750. (b) Dupont, J.; Pfeffer, M.; Spencer, J. Eur. J. Inorg. Chem. 2001, 1971. (c) van der Boom, M. E.; Milstein, D. Chem. Rev. 2003, 103, 1759. (d) Singleton, J. T. Tetrahedron 2003, 59, 1837. 
Scheme 1. PCP-Pincer Ru(II)-Catalyzed Hydrogen Transfer Reaction of Cyclohexanone in a 2-Propanol/Base Mixture

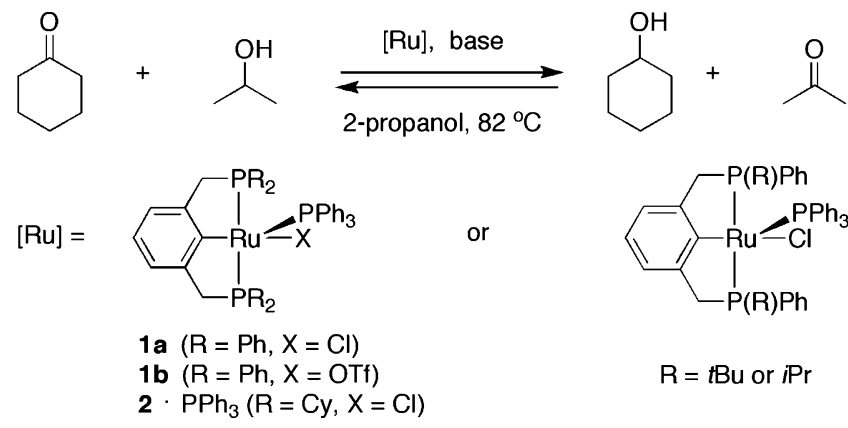

or E,C-ligand allows for the formation of long-lived, catalytically active species, which therefore may have great potential use in future synthetic methods. Importantly, with PCP-pincer Ru(II) complexes 1a, $\mathbf{1 b}$, and $\mathbf{2}$ the duration of the pretreatment time of the precursors with base in 2-propanol was critical to obtain good activity. ${ }^{2}$

Ruthenium dihydride compounds are proposed to be the actual catalytically active species in hydrogen transfer reactions. ${ }^{7}$ However, in the case of PCP-Ru(II) complexes the formation of such species has not been unambiguously established. ${ }^{2 b}$ Isolated monohydride derivatives of $\mathbf{2}$ have been applied as catalyst precursors in the presence of base. ${ }^{2 b}$ A slightly higher catalytic activity was attained. Nevertheless, the use of the more robust chloride $\mathbf{2}$ was found to be preferred over the monohydrides, due to the sensitivity of the hydride species and its subsequent deactivation in catalysis. ${ }^{2 b}$

Despite extensive research, the mechanism and, in turn, the steric and electronic effects of the PCP-pincer ligands on the catalytic activity of the ruthenium metal centers have yet to be determined systematically. In our previous investigations we found that the catalytic activity drops with increasing bulk of the phosphorus substituents. ${ }^{2 \mathrm{c}}$ Therefore, we consider here the possibility to investigate electronic effects in $\mathrm{PCP}-\mathrm{Ru}$ (II)-based hydrogen transfer by varying the donor properties of the $\mathrm{P}$ atoms by substitution of the para phenyl hydrogens of the $\left[\mathrm{C}_{6} \mathrm{H}_{3}\right.$ $\left.\left\{\mathrm{CH}_{2} \mathrm{P}\left(\mathrm{C}_{6} \mathrm{H}_{5}\right)_{2}\right\}_{2}-2,6\right]^{-}$pincer anionic ligand with $\mathrm{MeO}$ and $\mathrm{CF}_{3}$ groups. The position of the $\mathrm{MeO}$ and $\mathrm{CF}_{3}$ substituents in the ligands $\left[\mathrm{C}_{6} \mathrm{H}_{3}\left\{\mathrm{CH}_{2} \mathrm{P}\left(p-\mathrm{MeOC}_{6} \mathrm{H}_{4}\right)_{2}\right\}_{2}-2,6\right]^{-}$(PCPOMe; 3, Scheme 2) and $\left[\mathrm{C}_{6} \mathrm{H}_{3}\left\{\mathrm{CH}_{2} \mathrm{P}\left(p-\mathrm{CF}_{3} \mathrm{C}_{6} \mathrm{H}_{4}\right)_{2}\right\}_{2}-2,6\right]^{-}\left(\mathrm{PCP}^{\mathrm{CF}} 3\right.$; 4, Scheme 2 ) enables modification of electronic properties of the corresponding P-sites with minimal steric perturbation. ${ }^{8}$ The catalytic activity of the corresponding $\mathrm{PCP}-\mathrm{Ru}(\mathrm{II})$ complexes $[\mathrm{RuCl}-$ $\left.\left(\mathrm{PCP}^{\mathrm{OMe}}\right)\left(\mathrm{PPh}_{3}\right)\right]($ 5, Scheme 2$)$ and $\left[\mathrm{RuCl}\left(\mathrm{PCP}^{\mathrm{CF}}\right)\left(\mathrm{PPh}_{3}\right)\right](\mathbf{6}$, Scheme 2) has been investigated, as well as of the $\mathrm{Ru}(\mathrm{II})$ complex $\left[\mathrm{RuCl}\left(\mathrm{PCP}^{\mathrm{F} 20}\right)\left(\mathrm{PPh}_{3}\right)\right]^{9}(\mathbf{8 a}$, Scheme 2) containing the electron-withdrawing $\left[\mathrm{C}_{6} \mathrm{H}_{4}\left\{\mathrm{CH}_{2} \mathrm{P}\left(\mathrm{C}_{6} \mathrm{~F}_{5}\right)_{2}\right\}_{2}-2,6\right]^{10}\left(\mathrm{PCP}^{\mathrm{F} 20}\right)$ (7) $\mathrm{PCP}$-pincer ligand and its triflate analogue (8b, Scheme 2). However, ligand $\mathbf{7}$ is expected to also exert considerable steric effects on the ruthenium center because of its ortho-fluorine substituents in all four $\mathrm{P}\left(\mathrm{C}_{6} \mathrm{~F}_{5}\right)$ rings.

NMR studies and ESI-MS measurements were performed in order to shed light on the PCP-pincer Ru species formed when

(7) Clapham, S. E.; Hadzovic, A.; Morris, R. H. Coord. Chem. Rev. 2004, 248, 2201.

(8) Tolman, C. A. Chem. Rev. 1977, 77, 315.

(9) Gagliardo, M.; Chase, P. A.; Lutz, M.; Spek, A. L.; Hartl, F.; Havenith, R. W. A.; van Klink, G. P. M.; van Koten, G. Organometallics $\mathbf{2 0 0 5}, 24,4553$.

(10) Chase, P. A.; Gagliardo, M.; van Klink, G. P. M.; Lutz, M.; Spek, A. L.; van Koten, G. Organometallics 2005, 24, 2016. the $\left[\mathrm{RuCl}(\mathrm{PCP})\left(\mathrm{PPh}_{3}\right)\right]$ catalyst precursors $\mathbf{5}, \mathbf{6}, \mathbf{8 a}, \mathbf{8 b}$, and $\mathbf{9}$ $\left(\left[\mathrm{RuCl}\left(\mathrm{PCP}^{\mathrm{iPr}}\right)\left(\mathrm{PPh}_{3}\right)\right]\right.$ are pretreated in 2-propanol in the presence of an excess of base.

\section{Results and Discussion}

Synthesis. The $p-\mathrm{MeO}(3)$ and $p-\mathrm{CF}_{3}$ (4) ligands have been synthesized according to a previously described procedure for the preparation of the $\mathrm{C}_{6} \mathrm{~F}_{5}$ ligand $7^{10}($ Scheme 2$)$. This procedure involves the 1:2 molar reaction of the bis-Grignard reagent $\left[\mathrm{C}_{6} \mathrm{H}_{4}\left(\mathrm{ClMgCH}_{2}\right)_{2}-1,3\right]^{11}$ with the phosphines $\left(p-\mathrm{MeOC}_{6} \mathrm{H}_{4}\right)_{2}-$ $\mathrm{PCl}^{12}$ and $\left(p-\mathrm{CF}_{3} \mathrm{C}_{6} \mathrm{H}_{4}\right)_{2} \mathrm{PCl},{ }^{13}$ respectively. In contrast to 7 , which is stable to air and moisture, $\mathbf{3}$ and $\mathbf{4}$ are sensitive to $\mathrm{O}_{2}$, due to facile oxidation of the phosphorus centers.

The corresponding ruthenium(II) complexes 5, $\mathbf{6}$, and $\mathbf{8 a}^{9}$ have been prepared via the transcyclometalation (TCM) reaction, an efficient method for the preparation of achiral ${ }^{14}$ and chiral ${ }^{2 b, 15}$ $\left[\mathrm{RuCl}(\mathrm{PCP})\left(\mathrm{PPh}_{3}\right)\right]$ complexes. Thus, reaction of the complex $\left[\mathrm{RuCl}\left\{\mathrm{C}_{6} \mathrm{H}_{3}\left(\mathrm{CH}_{2} \mathrm{NMe}_{2}\right)_{2}-2,6\right\}\left(\mathrm{PPh}_{3}\right)\right]^{16}\left(\left[\mathrm{RuCl}(\mathrm{NCN})\left(\mathrm{PPh}_{3}\right)\right]\right.$, Scheme 2) with the PCP-pincer ligands 3,4 , and 7 , respectively, in 1:1 molar ratio at $80^{\circ} \mathrm{C}$, afforded the air-sensitive $\mathbf{5}$ and $\mathbf{6}$, respectively, as deep green-colored solids and the remarkably air/moisture-stable $\mathbf{8 a}$ as a red-colored powder.

The spectroscopic properties of both $\mathbf{5}$ and $\mathbf{6}$ are similar to those reported for $\mathbf{1 a}$ and $\mathbf{2}$, implying that the two compounds have similar structures, i.e., square pyramidal structures with the $\mathrm{PPh}_{3}$ ligand occupying the apical position. ${ }^{2,15}$ The ${ }^{1} \mathrm{H}$ NMR spectrum of both 5 and $\mathbf{6}$, recorded in $\mathrm{CD}_{2} \mathrm{Cl}_{2}$ at room temperature, displayed two sets of virtual doublets of triplets $\left({ }^{2} J_{\mathrm{HH}}=16 \mathrm{~Hz}\right.$ and $\left.{ }^{2} J_{\mathrm{PH}}=6 \mathrm{~Hz}\right)$ for the methylene protons of the PCP-pincer ligand. This indicates that the two $\mathrm{PR}_{2}$ groups are trans to each other and that the PCP-ligand is coordinated to the ruthenium(II) center in a meridional fashion. ${ }^{2,15}$ In the ${ }^{1} \mathrm{H}$ NMR spectrum of $\mathbf{5}$ and the ${ }^{19} \mathrm{~F}$ NMR spectrum of $\mathbf{6}$ two resonance patterns are found for the $\mathrm{MeOC}_{6} \mathrm{H}_{4}$ and $\mathrm{CF}_{3} \mathrm{C}_{6} \mathrm{H}_{4}$ groups, respectively, indicating that in both complexes the ( $p$ $\left.\mathrm{MeOC}_{6} \mathrm{H}_{4}\right)$ and $\left(p-\mathrm{CF}_{3} \mathrm{C}_{6} \mathrm{H}_{4}\right)$ groups are diastereotopic. The ${ }^{31} \mathrm{P}-$ $\left\{{ }^{1} \mathrm{H}\right\}$ NMR spectra exhibit one doublet for the equivalent $\mathrm{PR}_{2}$ groups of the respective PCP-pincer ligands and one triplet for the apical $\mathrm{PPh}_{3}$ ligand, arising from ${ }^{2} J_{\mathrm{PP}}$ coupling with the cispositioned $\mathrm{PR}_{2}$ groups. ${ }^{2,15}$ Consistent with this geometry, the ${ }^{13} \mathrm{C}$ NMR spectra for 5 and $\mathbf{6}$ show two characteristic resonances: one virtual triplet resonance for the benzylic carbons and a doublet $\mathrm{Ru}-\mathrm{C}_{\mathrm{ipso}}$ resonance $\left({ }^{2} J_{\mathrm{CP}} \approx 14 \mathrm{~Hz}\right) \cdot{ }^{2,15}$

Since the low activity of $\mathbf{8 a}$ (vide infra Table 1, entry 2) might be ascribed to strong coordination of the chloride anion, also the corresponding triflato (=trifluoromethanesulfonato; OTf = $\left.\left[\mathrm{CF}_{3}(\mathrm{O})_{2} \mathrm{SO}^{-}\right]\right)$complex $\left[\mathrm{Ru}\left(\mathrm{PCP}^{\mathrm{F} 20}\right)\left(\mathrm{PPh}_{3}\right)\right](\mathrm{OTf})$ (8b) was prepared by reacting $\mathbf{8 a}$ with an equimolar amount of $\mathrm{Ag}(\mathrm{OTf})$.

(11) (a) Lappert, M. F.; Martin, T. R.; Atwood, J. L.; Hunter, W. E. J Chem. Soc., Chem. Commun. 1980, 476. (b) Lappert, M. F.; Martin, T. R.; Raston, C. L.; Skelton, B. W.; White, A. H. J. Chem. Soc., Dalton Trans. 1982, 1959.

(12) Ogasawara, M.; Takizawa, K.; Hayashi, T. Organometallics 2002, $21,4853$.

(13) Unruh, J. H.; Christenson, J. R. J. Mol. Catal. 1982, 14, 19.

(14) Dani, P.; Karlen, T.; Gossage, R. A.; Smeets, W. J. J.; Spek, A. L.; van Koten, G. J. Am. Chem Soc. 1997, 119, 11317. (b) Dani, P.; Albrecht, M.; van Klink, G. P. M.; van Koten, G. Organometallics 2000, 19, 4468.

(15) (a) Karlen, T.; Dani, P.; Grove, D. M.; Steenwinkel, P.; van Koten, G. Organometallics 1996, 15, 5687. (b) Jia, G.; Lee, H. M.; Xia, H. P.; Williams, I. D. Organometallics 1996, 15, 5453. (c) van der Boom, M. E.; Kraatz, H.-B.; Hassner, L.; Ben-David, Y.; Milstein, D. Organometallics 1999, 18, 3873. (d) Dani, P.; van Klink, G. P. M.; van Koten, G. Eur. J. Inorg. Chem. 2000, 7, 1465.

(16) Sutter, J.-P.; James, S. L.; Steenwinkel, P.; Karlen, T.; Grove, D. M.; Veldman, N.; Smeets, W. J. J.; Spek, A. L.; van Koten, G. Organometallics 1996, 15, 941. 
Scheme 2. Synthesis of $\left[\operatorname{RuCl}\left(\mathrm{PCP}^{\mathrm{R}}\right)\left(\mathrm{PPh}_{3}\right)\right]$ Complexes via the Transcyclometalation $(\mathrm{TCM})$ Reaction

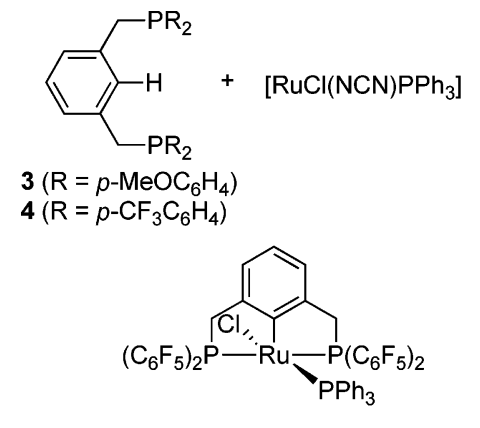

$8 \mathbf{a}$

Table 1. Hydrogen Transfer Reaction Catalyzed by PCP-Pincer Ru(II) Complexes ${ }^{a}$

\begin{tabular}{cccc}
\hline entry & $\begin{array}{c}\text { catalyst precursor } \\
{\left[\mathrm{RuCl}(\mathrm{L})\left(\mathrm{PPh}_{3}\right)\right]}\end{array}$ & $\mathrm{TOF}\left(\mathrm{h}^{-1}\right)^{b}$ & conversion $(\%) / t(\mathrm{~min})$ \\
\hline 1 & $\mathrm{PCP}^{\mathrm{Ph}}(\mathbf{1 a})$ & 33600 & $98 / 10$ \\
2 & $\mathrm{PCP}^{\mathrm{F} 20}(\mathbf{8 a})$ & 41 & $98 / 780$ \\
3 & $\mathrm{PCP}^{\mathrm{OMe}}(\mathbf{5})$ & 8000 & $96 / 30$ \\
4 & $\mathrm{PCP}^{\mathrm{CF} 3}(\mathbf{6})$ & 35700 & $98 / 10$ \\
5 & $\mathrm{PCP}^{i \operatorname{Pr}}(\mathbf{9})$ & 980 & $98 / 300$
\end{tabular}

${ }^{a}$ Reaction conditions: $2.0 \mathrm{mmol}$ of cyclohexanone; $[\mathrm{Ru}]=0.1 \mathrm{~mol} \%$; $2 \mathrm{~mL}$ of 2-propanol; $[\mathrm{NaOH}]:[\mathrm{Ru}]=20: 1 ; T=82{ }^{\circ} \mathrm{C} ; \mathrm{N}_{2}$ atmosphere Pretreatment time $=1 \mathrm{~h} .{ }^{b}$ Turnover frequency $(\mathrm{TOF})$ calculated at $20 \%$ conversion.

Complex $\mathbf{8 b}$ was isolated in good yield as a purple-colored solid. The ${ }^{1} \mathrm{H}$ NMR spectrum showed that the benzylic hydrogens are diastereotopic. Moreover, the small ${ }^{2} J_{\mathrm{CP}}$ coupling constant of the doublet for the $\mathrm{C}_{\mathrm{ipso}}$ in the ${ }^{13} \mathrm{C}$ NMR spectra indicates the mutual cis arrangement of $\mathrm{C}_{\mathrm{ipso}}$ and $\mathrm{PPh}_{3}$. However, analogously as found for $\mathbf{1 b},{ }^{15 a}{ }^{31} \mathrm{P}\left\{{ }^{1} \mathrm{H}\right\}$ NMR spectroscopy shows that $\mathbf{8 b}$ exhibits temperature-dependent behavior. The ${ }^{31} \mathrm{P}\left\{{ }^{1} \mathrm{H}\right\}$ NMR spectrum contains a broad resonance for the $\mathrm{PPh}_{3}$ ligand (55.6 ppm) and a sharp doublet resonance for the PCP-pincer P-donor atoms $\left(25.8 \mathrm{ppm},{ }^{2} J_{\mathrm{PP}}=35 \mathrm{~Hz}\right)$. The position and the multiplicity of the resonances point to a meridional coordination of the PCP-pincer ligand as well as the cis arrangement between the $\mathrm{P}\left(\mathrm{C}_{6} \mathrm{~F}_{5}\right)$ donor atoms and the $\mathrm{PPh}_{3}$ ligand. The broad signal for the $\mathrm{PPh}_{3}$ ligand may be ascribed to the occurrence of an association/dissociation process that involves the triflate ion. In fact, the ${ }^{19} \mathrm{~F}$ NMR spectrum of $\mathbf{8 b}$ recorded in $\mathrm{CH}_{2} \mathrm{Cl}_{2}$ at room temperature displayed a singlet at $-80.47 \mathrm{ppm}$ consistent with the presence of a noncoordinating triflato group. ${ }^{17}$ Molecular modeling confirms that the bulkiness of the $\mathrm{P}\left(\mathrm{C}_{6} \mathrm{~F}_{5}\right)_{2}$ groups would exert considerable pressure to a $\eta^{1}-\mathrm{O}$ monodentate coordinated triflate group. Moreover, the structure of $\mathbf{8 a}$ in the solid state has revealed that the ortho-F substituents are ideally positioned for intramolecular coordination to a vacant site at the ruthenium center. Indeed, analysis of the IR spectrum of solid $\mathbf{8 b}$ in the region $1000-1300 \mathrm{~cm}^{-1}$ shows broad absorptions for the asymmetric $\mathrm{S}-\mathrm{O}$ stretching at 1293 and at $1261 \mathrm{~cm}^{-1}$, which are characteristic of an uncoordinated $\mathrm{OTf}^{-}$ion. ${ }^{18}$

Hydrogen Transfer Catalysis. The catalytic activity of the novel complexes 5 (entry 3) and $\mathbf{6}$ (entry 4) as hydrogen transfer catalyst precursors using cyclohexanone as a model substrate was studied and compared to that of $\mathbf{1 a}$ (entry 1).

(17) van Stein, G. C.; van Koten, G.; Vrieze, K.; Brevard, C.; Spek, A. L. J. Am. Chem. Soc. 1984, 106, 4486.

(18) Dedert, P. L.; Thompson, J. S.; Ibers, J. A.; Marks. T. J. Inorg. Chem. 1982, 21, 969.
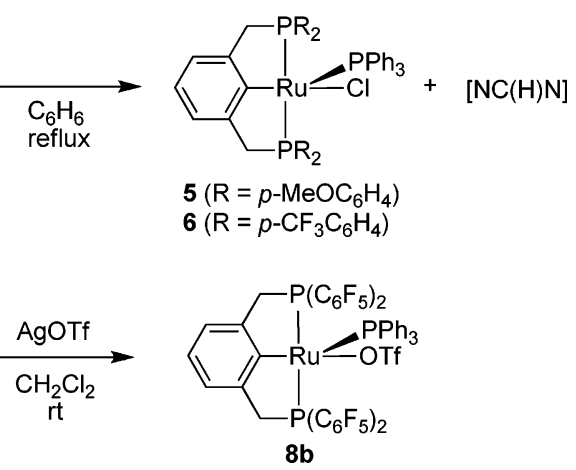

The catalytic experiments have been performed following pretreatment of the catalyst precursor for $1 \mathrm{~h}$ in refluxing 2-propanol $\left(82^{\circ} \mathrm{C}\right)$ in the presence of a 20 -fold excess of base. For all the complexes the elevated temperature as well as the presence of an excess of base were essential for a high catalytic activity. Addition of the base to solutions of either $\mathbf{5}$ or $\mathbf{6}$ caused a color change of the solution from green to yellow. The results, visualized in Figure 1, show that after $1 \mathrm{~h}$ of pretreatment the reaction starts immediately upon addition of the substrate $(t=$ 0 ), and no further induction period was observed. Moreover, no deactivation was observed and full conversion could be attained in 10-20 min.

The results reported in Table 1 highlight that PCP-pincer Ru(II) complexes $\mathbf{5}$ and $\mathbf{6}$ are highly active precursors and initial TOFs (at $20 \%$ conversion) of 8000 and $38000 \mathrm{~h}^{-1}$ were obtained. It must be noted that the initial TOFs for the majority of ruthenium(II) complexes do not exceed a few thousands per hour. ${ }^{7}$ Comparison of the entries in Table 1 reveals that the precursors $\mathbf{1 a}, \mathbf{5}$, and $\mathbf{6}$ containing bisarylphosphine PCP-pincer ligands (entries 1, 3, and 4, respectively) are more active precatalysts than the complex containing the bulky, electronrich bis(isopropyl)phosphine PCP-pincer ligand 9 (entry 5). Complexes 1a and $\mathbf{6}$ showed similar activities and are the most active of the series.

So far, for all the $\mathrm{PCP}-\mathrm{Ru}(\mathrm{II})$ systems reported, the duration of the pretreatment time appeared to be critical to activity. ${ }^{2}$ The fact that a pretreatment time is required indicates that from the starting complexes new intermediates are formed. Interestingly, in the case of $\mathbf{6}$, the observed activity is independent of any pretreatment. The similar activity profiles with 0 and $1 \mathrm{~h}$ pretreatment time (Figure 2) suggest that the catalytically active

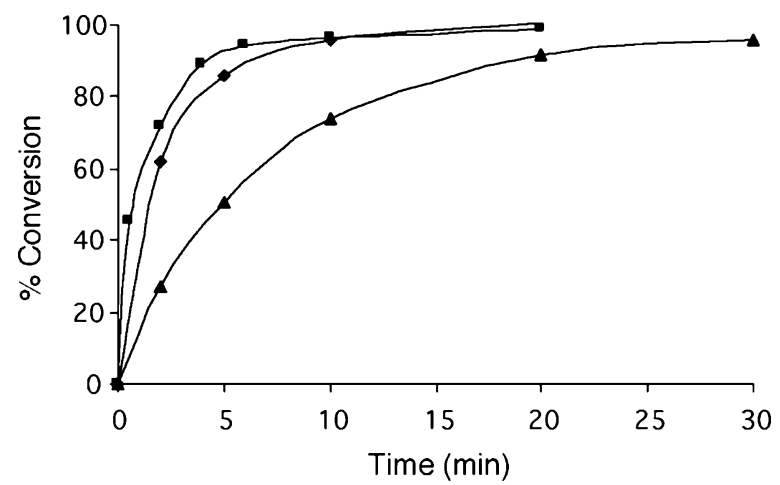

Figure 1. Electronic effect on the hydrogen transfer reaction of cyclohexanone catalyzed by $\mathbf{6}(\mathbf{\square}), \mathbf{1 a}(\diamond)$, and $\mathbf{5}(\mathbf{\Delta})([\mathrm{Ru}]=0.1 \%$ $\mathrm{mol})$ in 2-propanol in the presence of base $(\mathrm{NaOH}:[\mathrm{Ru}]=20: 1)$ at $T=82{ }^{\circ} \mathrm{C}$. Pretreatment time $=1 \mathrm{~h}$. 


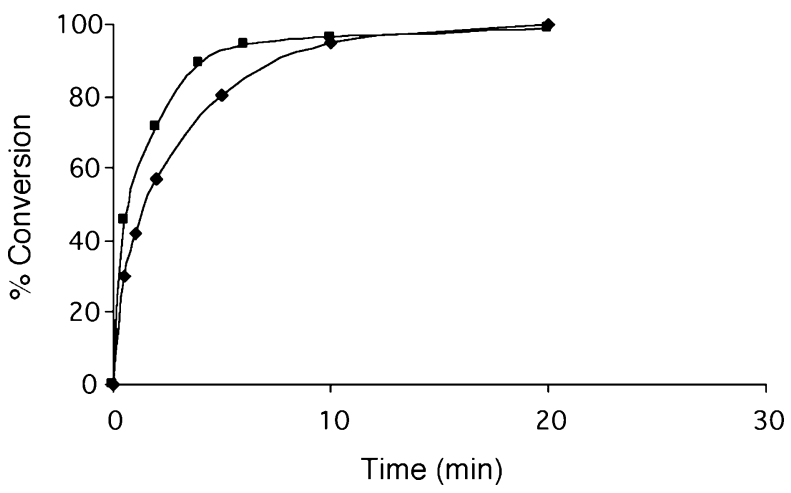

Figure 2. Effect of pretreatment time on the hydrogen transfer reaction of cyclohexanone catalyzed by $6([\mathrm{Ru}]=0.1 \% \mathrm{~mol})$ in 2-propanol in the presence of base $(\mathrm{NaOH}:[\mathrm{Ru}]=20: 1)$ at $T=82$ ${ }^{\circ} \mathrm{C}$. Pretreatment time $=1 \mathrm{~h}(\boldsymbol{\square})$ and $0 \mathrm{~h}(\diamond)$.

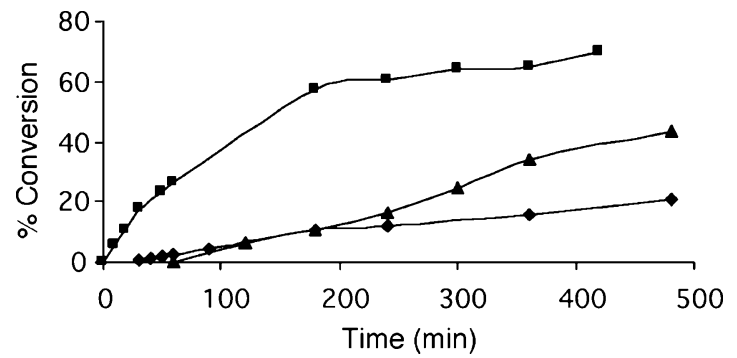

Figure 3. Effect of pretreatment time on the hydrogen transfer reaction of cyclohexanone catalyzed by $\mathbf{8 a}([\mathrm{Ru}]=0.1 \% \mathrm{~mol})$ in 2-propanol in the presence of base $(\mathrm{NaOH}:[\mathrm{Ru}]=20: 1)$ at $T=82$ ${ }^{\circ} \mathrm{C}$. Pretreatment time $=0 \mathrm{~h}(\boldsymbol{\square}), 1 \mathrm{~h}(\bullet)$, and $2 \mathrm{~h}(\boldsymbol{\Delta})$.

species is formed rapidly when 6 reacts with 2-propanol in the presence of base and that the resulting species is stable in the absence of substrate. Regrettably, the intrinsic higher catalytic activity of $\mathbf{6}$ did not allow the observation of deactivation pathways at the applied substrate to catalyst ratio. Replacement of phenyl rings in the $\mathrm{R}_{2} \mathrm{P}$ groups by strongly electronwithdrawing $\mathrm{C}_{6} \mathrm{~F}_{5}$ rings, which, however, are also orthohindering through the ortho-fluorine atoms (vide supra) (entry 2 ), resulted in a dramatic decrease of the catalytic activity, cf. $8 \mathbf{a}$ with $1 \mathrm{a}$.

In contrast to the findings for $\mathbf{5}$ and $\mathbf{6}$, the reaction profile of the reaction catalyzed by $\mathbf{8 a}$ (Figure 3 ) is strongly dependent on the length of the pretreatment time. As compared with 1a and $\mathbf{5}$, which reach the highest activity after $1 \mathrm{~h}$ of pretreatment, 8a suffered from a long induction time (Figure 3). Moreover, after the induction period, a low initial activity was observed while the catalytic solution undergoes deactivation with time. After 400 min conversion ceased at $20 \%$. Application of a longer pretreatment time $(2 \mathrm{~h})$ led to analogous results. However, in this case, a longer induction period but a slightly higher activity are attained (Figure 3). Interestingly, when substrate was directly added to a fresh solution of $\mathbf{8 a}$, i.e., without applying any pretreatment, no induction period was observed and a higher activity was found. Full conversion was reached in $13 \mathrm{~h}$, accompanied by the formation of traces of aldol condensation products. ${ }^{19}$

These observations suggest that during pretreatment several species are formed in different concentrations and with intrinsically different activities, which all suffer from deactivation under pretreatment conditions in the absence of substrate. In contrast to what is observed with $\mathbf{1 a}, \mathbf{5}$, and $\mathbf{6}$, addition of the base to

(19) Analysis of the aldol products (GS-MS) in the reaction mixture revealed that they were the result of reaction of acetone with the substrate.

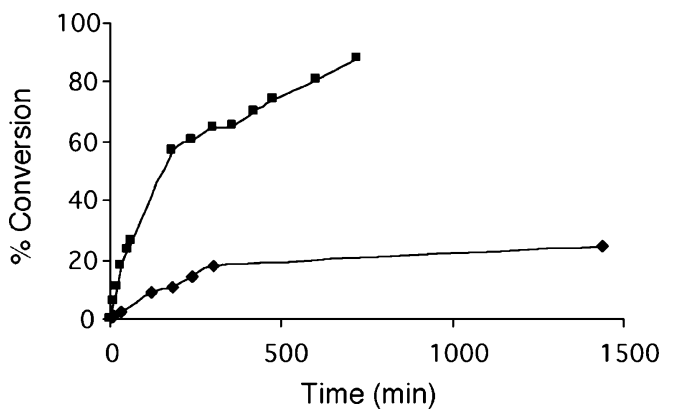

Figure 4. Hydrogen transfer reaction of cyclohexanone catalyzed by $\mathbf{8 a}(\mathbf{\square})$ and $\mathbf{8 b}(\bullet)([\mathrm{Ru}]=0.1 \% \mathrm{~mol})$ in 2-propanol in the presence of base $(\mathrm{NaOH}:[\mathrm{Ru}]=20: 1)$ at $T=82{ }^{\circ} \mathrm{C}$. Pretreatment time $=0 \mathrm{~h}$

8a does not immediately cause change of the color of the solution. Only after prolonged heating under catalysis conditions does the color of the solution turn slowly from red to yellow, which seemed to indicate that initially $\mathbf{8 a}$ remained unchanged. Analysis of the ${ }^{1} \mathrm{H},{ }^{31} \mathrm{P}\left\{{ }^{1} \mathrm{H}\right\}$, and ${ }^{19} \mathrm{~F}$ NMR spectra recorded during the pretreatment period revealed that eventually also $\mathbf{8 a}$ underwent a transformation in the presence of base. A series of well-resolved ${ }^{19} \mathrm{~F}$ NMR signals was observed indicating the presence of at least three different species, which however could not be identified. We are aware that metal-mediated carbonfluorine bond activation in $\mathrm{P}\left(\mathrm{C}_{6} \mathrm{~F}_{5}\right)_{2}$ groups has been observed in the presence of an excess of alkoxide. ${ }^{20}$ However, from the obtained NMR data it can be excluded that under the applied experimental conditions substitution of the para-fluorine atoms by the isopropoxide anion occurred. ${ }^{20}$

In order to study whether the low activity of $8 \mathbf{a}$ was due to the strong coordination of the chloride ligand, the cationic complex $\mathbf{8 b}$ with the triflate ion was used as catalyst precursor (Figure 4). The results indicated that $\mathbf{8 b}$ had an even lower activity than that found for $\mathbf{8 a}$. It is of interest to note that this compound has a remarkable stability to air and moisture, whereas its protio analogue is extremely reactive and difficult to handle. ${ }^{15}$ The low reactivity of the Lewis acidic complexes $\mathbf{8 a}$ and $\mathbf{8 b}$ can be ascribed to a pronounced deactivation (e.g., strong coordination of substrate, 2-propanol, acetone) or decomposition of the catalytically active species formed during the pretreatment period. However, in analogy with what was observed with the chiral complexes $(S, S)$ - $\left[\mathrm{RuCl}\left(\mathrm{PCP}^{t \mathrm{Bu}, \mathrm{Ph}}\right)\right.$ $\left.\left(\mathrm{PPh}_{3}\right)\right]$ and $(S, S)-\left[\mathrm{RuCl}\left(\mathrm{PCP}{ }^{i \mathrm{Pr}, \mathrm{Ph}}\right)\left(\mathrm{PPh}_{3}\right)\right]$, containing bulky PCP-pincer ligands, the reactivity of the active species formed during the pretreatment period may be considerably altered by the steric effects exerted by the bulky $\mathrm{P}\left(\mathrm{C}_{6} \mathrm{~F}_{5}\right)$ groups. ${ }^{21}$

Fogg and co-workers reported the formation of the neutral complex $\left[\mathrm{Ru}(\mathrm{H})\left(\mathrm{PCP}^{\mathrm{Cy}}\right)\left(\mathrm{N}_{2}\right)\left(\mathrm{PPh}_{3}\right)\right]$ when $\left[\mathrm{RuCl}\left(\mathrm{PCP}^{\mathrm{Cy}}\right)\left(\mathrm{PPh}_{3}\right)\right]$ (2) is refluxed in a 2-propanol/KO $t \mathrm{Bu}$ mixture. ${ }^{2 \mathrm{~b}} \mathrm{We}$ have not attempted to isolate analogous species when the catalyst precursors are heated to reflux in a $\mathrm{NaOH} / \mathrm{NaO} i \mathrm{Pr}$ mixture. However, to rule out whether the activity of the catalytically active species is influenced by nitrogen coordination, we carried out the catalysis under an $\mathrm{Ar}$ atmosphere. With the highly active complexes 1a, 5, 6, and 9 the results were essentially identical to those obtained under $\mathrm{N}_{2}$. When the less active complexes 8a and $\mathbf{8 b}$ were used, the initial rate was slightly higher. This is probably due to the fact that coordination of $\mathrm{N}_{2}$ to the ruthenium stabilizes, to a certain extent, catalytically active species formed

(20) Mohr, W.; Stark, G. A.; Jiao, H.; Gladysz, J. A. Eur. J. Inorg. Chem. 2001, 925 .

(21) Gagliardo, M.; Havenith, R. W. A.; van Klink, G. P. M.; van Koten, G. J. Organomet. Chem. 2006, 691, 4411 . 


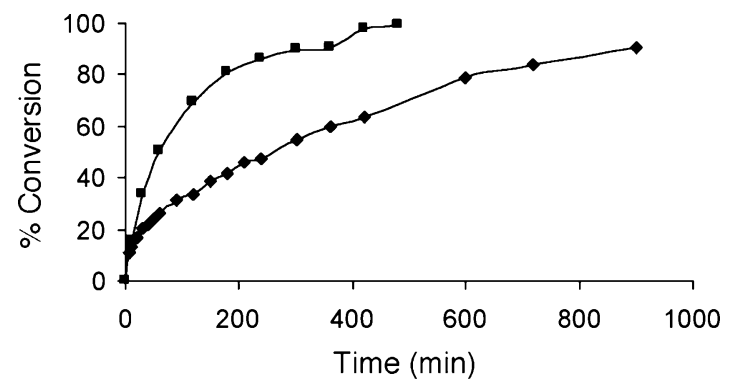

Figure 5. Effect of pretreatment on the hydrogen transfer reaction of cyclohexanone catalyzed by $\mathbf{9}([\mathrm{Ru}]=0.1 \% \mathrm{~mol})$ in 2-propanol in the presence of base $(\mathrm{NaOH}:[\mathrm{Ru}]=20: 1)$ at $T=82{ }^{\circ} \mathrm{C}$. Pretreatment time $=1 \mathrm{~h}(\boldsymbol{\square})$ and $0 \mathrm{~h}(\bullet)$.

during the pretreatment, decreasing their susceptibility toward decomposition.

Mechanistic Aspects. In agreement with previous studies, our results show that the use of a strong base such as $\mathrm{NaOH}$ as promotor in the hydrogen transfer is essential to effect conversion. ${ }^{2,7}$ As already reported for analogous systems, no reaction occurs in the absence of base or if its concentration is too low, whereas in the presence of a large excess (30-100 equiv to the catalyst precursor) the catalyst precursors decompose quite fast. Since for most of the analyzed systems the pretreatment of the catalyst precursor with an excess of a basic promotor is absolutely necessary, attention had been directed toward the identification of the species formed during the pretreatment time. Complex $\left[\mathrm{RuCl}\left\{\mathrm{C}_{6} \mathrm{H}_{3}\left(\mathrm{CH}_{2} \mathrm{P}(i \mathrm{Pr})_{2}\right)_{2}-2,6\right\}\left(\mathrm{PPh}_{3}\right)\right]^{15 \mathrm{c}}$ (9), which has a reaction profile similar to those of $\mathbf{1 a}$ and $\mathbf{6}$ (Figure 5), was chosen to identify and investigate such species in more detail.

Reaction of 9 in refluxing 2-propanol in the presence of an excess of $\mathrm{NaOH}$ was monitored by taking aliquots of the reaction mixture and subsequently analyzing them by ${ }^{1} \mathrm{H}$ and ${ }^{31} \mathrm{P}\left\{{ }^{1} \mathrm{H}\right\}$ NMR spectroscopy in $\mathrm{C}_{6} \mathrm{D}_{6}$. Within a few minutes, 9 reacted completely to several hydride species, including the complex that was identified as $\mathrm{Na}\left[\mathrm{Ru}(\mathrm{H})\left(\mathrm{PCP}{ }^{i \mathrm{Pr}}\right)(\mathrm{O} i \mathrm{Pr})\left(\mathrm{PPh}_{3}\right)\right]$ (10, Scheme 3). It turned out that after $1 \mathrm{~h} \mathbf{1 0}$ is quantitatively formed and is the only species present in solution. The ${ }^{1} \mathrm{H}$ NMR spectrum of $\mathbf{1 0}$ in $\mathrm{C}_{6} \mathrm{D}_{6}$ displays two doublet of triplets at -9.17 ppm $\left({ }^{2} J_{\mathrm{HP}}=20.7 \mathrm{~Hz}\right.$ and $\left.{ }^{2} J_{\mathrm{HP}}=82.2 \mathrm{~Hz}\right)$, indicating that the hydride ligand is trans to the $\mathrm{PPh}_{3}$ ligand and cis to the phosphorus atoms of the PCP-pincer ligand. The proton signal for the $\mathrm{Ru}-\mathrm{OCH}$ moiety appears as a broad resonance at 3.83 ppm, while the ${ }^{13} \mathrm{C}$ NMR peak for the $\mathrm{OCH}$ moiety appears at $59.0 \mathrm{ppm}$. The ${ }^{31} \mathrm{P}\left\{{ }^{1} \mathrm{H}\right\}$ NMR spectrum shows a doublet at 72.1 ppm and a triplet at $35.8 \mathrm{ppm}\left({ }^{2} J_{\mathrm{PP}}=15.5 \mathrm{~Hz}\right)$ for the two equivalent phosphorus atoms of the PCP-pincer ligand and the $\mathrm{PPh}_{3}$ ligand, respectively. No additional peaks in the ${ }^{1} \mathrm{H}$ and ${ }^{31} \mathrm{P}\left\{{ }^{1} \mathrm{H}\right\}$ NMR spectra are observed upon prolonged heating of the reaction mixture. The quantitative formation of $\mathbf{1 0}$ under pretreatment is in agreement with the results communicated by Dani et al. ${ }^{2 \mathrm{a}}$ and with the formation of Ru-hydride-isopropoxide species obtained by refluxing analogous $\mathrm{Ru}(\mathrm{II})$ catalyst precursors in 2-propanol in the presence of an excess of $\mathrm{NaOH}$ or $\mathrm{NaOiPr} .^{4-7}$

In the presence of an excess of substrate, under reflux conditions, $\mathbf{1 0}$ undergoes transformation toward a new hydride species. The hydride region of the ${ }^{1} \mathrm{H}$ NMR spectra shows the appearance of an additional quartet $\left(-6.16 \mathrm{ppm},{ }^{2} J_{\mathrm{HP}}=21.3\right.$ $\mathrm{Hz}$ ), which may be attributed to a hydride $c i s$ to the $\mathrm{PPh}_{3}$ ligand. The ${ }^{31} \mathrm{P}\left\{{ }^{1} \mathrm{H}\right\}$ NMR spectrum shows an additional doublet at 71.4 ppm $\left({ }^{2} J_{\mathrm{PP}}=16.0 \mathrm{~Hz}\right)$ for the PCP-pincer ligand and a triplet at $48.5 \mathrm{ppm}\left({ }^{2} J_{\mathrm{PP}}=16.0 \mathrm{~Hz}\right)$ for the $\mathrm{PPh}_{3}$ ligand. Addition of an additional excess of cyclohexanone resulted in an increase of the latter signals. A rationalization for these observations is the presence of an equilibrium in which the coordinated isopropoxide ion in $\mathbf{1 0}$ is replaced by the substrate.

This binding of the isopropoxide anion to the ruthenium center in $\mathbf{1 0}$ in solution is supported by high-resolution ESI-MS measurements. In the ESI-MS $(+)$ spectrum the highest mass peak at $\mathrm{m} / z=958.7(70 \%)$ corresponds to the adduct $\{[\mathrm{Ru}-$ $\left.\left.(\mathrm{H})\left(\mathrm{PCP}{ }^{i \mathrm{Pr}}\right)(\mathrm{O} i \mathrm{Pr})\right] \mathrm{Na}\left[\mathrm{Ru}\left(\mathrm{PCP}^{i \mathrm{Pr}}\right)\right]\right\}^{+}$, showing the correct isotopic pattern for this formulation. The peak of the oxygencontaining adduct is also present $\left(\left[\mathrm{M}_{\text {adduct }}+\mathrm{O}\right]^{+} ; \mathrm{m} / \mathrm{z}=974.7\right.$; $50 \%$ ). Apart from these peaks, no other peaks were observed that could be assigned to a Ru-containing adduct or a ligand degradation product. The signals in the ${ }^{31} \mathrm{P}\left\{{ }^{1} \mathrm{H}\right\}$ NMR spectra confirmed the presence of resonances typical for the oxidized $\mathrm{P}(i \mathrm{Pr})_{2}$ group. The presence of $\left[\mathrm{M}_{\text {adduct }}+\mathrm{O}\right]^{+}$in the early stages of the pretreatment time shows that oxidation of the phosphorus atoms of the PCP ligand may constitute an important deactivation route. Our ESI-MS studies of reaction mixtures during the pretreatment time indicate that dimeric $\mathrm{Ru}$-alkoxide species are accessible under the applied conditions. However, we are aware that a detailed study is required in order to establish unambiguously whether the formation of these species is due to the presence of an excess of $\mathrm{NaOiPr}$.

In a separate experiment, the selective synthesis of $\mathbf{1 0}$ was attempted by reaction of 9 with exactly 2 equiv of $\mathrm{NaO} i \operatorname{Pr}$ in refluxing toluene. ${ }^{1} \mathrm{H}$ and ${ }^{31} \mathrm{P}\left\{{ }^{1} \mathrm{H}\right\} \mathrm{NMR}$ spectroscopy clearly demonstrated that at a 1:2 molar ratio of $\mathbf{9}$ and $\mathrm{NaiOPr}$, hydride 10 is present in a low amount. Addition of $\mathrm{NaO} i \mathrm{Pr}$ to a $1: 5$ or $1: 10$ molar ratio resulted in the steady increase of the signals related to $\mathbf{1 0}$ at the expense of the other signals. An almost quantitative formation of $\mathbf{1 0}$ was observed at 1:20 molar ratio (20-fold excess). These results indicate that a large excess of base is required in order to shift the equilibria depicted in Scheme 3 toward $\mathbf{1 0}$ and that several hydride species can coexist.

Several mechanisms have been proposed, in which monoand dihydride ruthenium complexes are key intermediates. ${ }^{7}$ Little is known about the mechanism of the PCP-Ru(II)catalyzed hydrogen transfer reaction. During the pretreatment time, no loss of PCP-pincer ligand or $\mathrm{PPh}_{3}$ ligand is observed. This suggests that the catalytically active species indeed contains $\left[\left(\right.\right.$ cis $\left.-\mathrm{PPh}_{3}\right)($ mer-PCP $\left.\left.) \mathrm{Ru}-\mathrm{H}\right]\right)$ as reaction platform. It seems likely that the reactivity of the Ru-hydride PCP-pincer species (Scheme 3) toward carbonyl substrates is high. In fact, it has been shown that the presence of a ligand such as $\mathrm{PPh}_{3}$ or $\mathrm{C}_{\mathrm{ipso}}$ with a high trans-influence trans to a hydride enhances the reactivity of this $\mathrm{Ru}-\mathrm{H}$ bond. ${ }^{7}$

On the basis of these observations and on the fact that loss of $\mathrm{PPh}_{3}$ has not been observed (see below), ${ }^{2 \mathrm{~b}}$ the catalytic cycle depicted in Scheme 3, based on the mechanisms proposed in the literature, ${ }^{7}$ can be envisaged. The cycle involves a hydrogen transfer reaction of coordinated ketones via an inner-sphere hydritic route. ${ }^{7}$

This cycle starts from the monohydride complex $\mathbf{A}$, which is formed by coordination of the ketone substrate to the $\mathrm{Ru}-$ hydride intermediate 12.22 This species could also be formed prior to the formation of $\mathbf{1 2}$ by loss of $\mathrm{NaO} i \mathrm{Pr}$ from $\mathbf{1 0}$. Complex $\mathbf{A}$ is subsequently converted into $\mathbf{B}$ via intramolecular addition of the hydride to the $\alpha-\mathrm{C}$ atom of the ketone. Recently, Baratta and co-workers obtained solid evidence for the formation of a ruthenium species by insertion of benzophenone into the $\mathrm{Ru}-\mathrm{H}$ bond of the complex $[\mathrm{Ru}(\mathrm{H})(\mathrm{CNN})(\mathrm{dppb})]\left(\mathrm{CNN}=6-\left(4^{\prime}-\right.\right.$

(22) Jia, G.; H. M.; Lee, I. D.; Wiiliams J. Organomet. Chem. 1997, 534, 173. 
Scheme 3. Mechanistic Proposal for the Hydrogen Transfer Reaction of Ketones Catalyzed by PCP-Pincer Ru(II) Complexes ${ }^{a}$

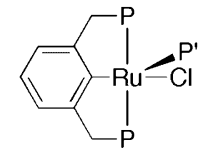

9

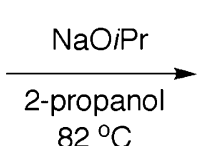

$82^{\circ} \mathrm{C}$

$\mathrm{P}^{\prime}=\mathrm{PPh}_{3}$

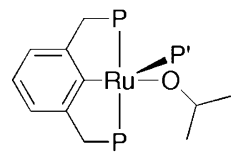

11

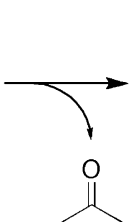

H

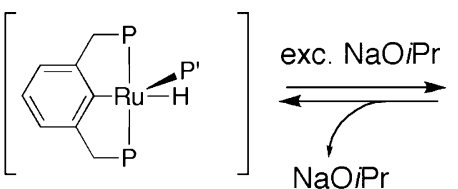

12

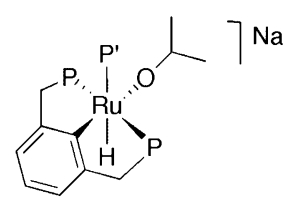

10
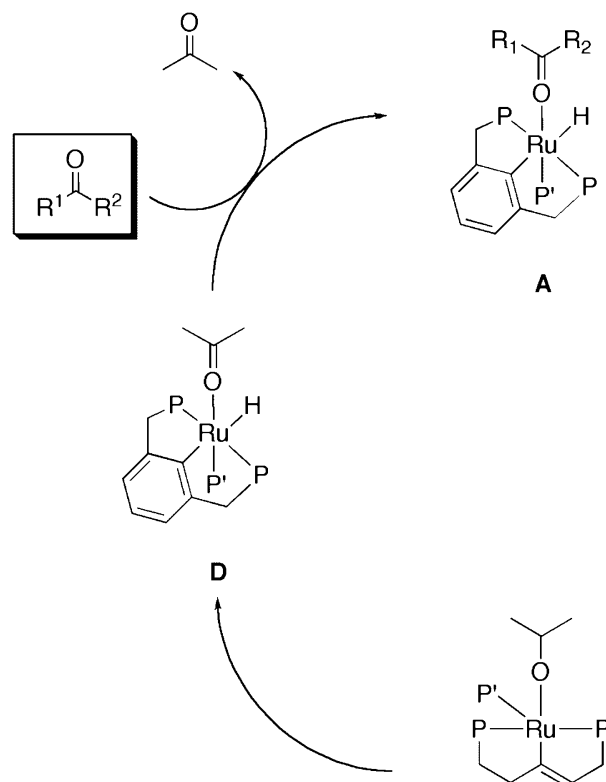

A
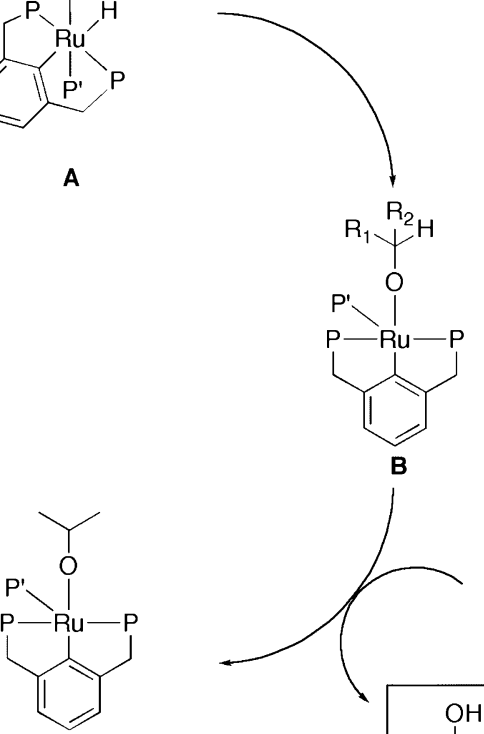

C

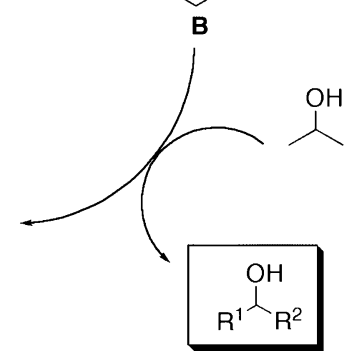

a In the catalytic cycle the drawings are not meant to show a particular stereochemistry.

methylphenyl)-2-pyridylmethylamine; $\mathrm{dppb}=\mathrm{Ph}_{2} \mathrm{P}\left(\mathrm{CH}_{2}\right)_{4}$ $\left.\mathrm{PPh}_{2}\right) .{ }^{3}$ The hydrogen transfer agent (2-propanol) releases the coordinated alkoxide by protonation, thereby forming $\mathbf{C}$ and the new alcohol. At this stage, the PCP-pincer ligand may play a crucial role by stabilizing the cationic charge developed at the metal center that is produced during the hydride transfer and prior to coordination of the isopropoxide anion to give $\mathbf{C}$. Subsequently, $\mathbf{C}$ delivers a hydride to the ruthenium center by $\beta$-H elimination giving D. Exchange of the oxidized hydrogen donor (acetone) for the substrate results in the formation of the monohydride $\mathbf{A}$, which is the start of the cycle.

The remarkable difference in activity between mono- and dihydride species made Bäckvall ${ }^{23}$ and Fogg $^{2 b}$ propose that instead of $\mathbf{A}$ a ruthenium-dihydride complex is formed as the catalytically active species in hydrogen transfer of ketones via related $\mathrm{Ru}$ systems. In this respect, the anionic complex $\mathbf{1 0}$ could be envisaged as a potential reservoir of such dihydride species. Formation of a dihydride species from $\mathbf{1 0}$ would require a loss of the $\mathrm{PPh}_{3}$ ligand in order to create a vacant coordination site available for an additional hydride. In the present reactions catalyzed by PCP-pincer ruthenium species the formation of $\mathrm{Ru}(\mathrm{H})_{2}$ and free $\mathrm{PPh}_{3}$ ligand has not been observed, in agreement with the results of Fogg and co-workers. ${ }^{2 b}$ Addition of an excess of $\mathrm{PPh}_{3}(5-10$ equiv to $\mathrm{Ru})$ results in a lower

(23) Aranyos, A.; Csjernyik, G.; Szabó, K.; Bäckwall, J.-E. J. Chem. Soc., Chem. Commun. 1999, 351. catalytic activity, in agreement with the results reported in the literature. $^{2 b}$ Unfortunately, these experiments do not prove, nor disprove, the loss of $\mathrm{PPh}_{3}$ during the catalytic cycle. Excess $\mathrm{PPh}_{3}$ could simply hamper catalysis by coordination to a vacant site. In this respect no definite conclusions may be drawn, even though the most active precursor, 6 , contains the most electrophilic $\mathrm{Ru}(\mathrm{II})$ center, from which decomplexation of $\mathrm{PPh}_{3}$ is less likely to occur.

Using the mechanism proposed in Scheme 3, the beneficial effect of the employment of the $\mathrm{PCP}^{\mathrm{CF} 3}$-pincer ligand containing $\mathrm{CF}_{3}$ electron-withdrawing groups on the formation of active species from 6 during the pretreatment time or in the catalytic cycle can be explained: a higher Lewis acidic character is expected to make the ruthenium center a better hydrogen abstractor. Thus, during the pretreatment time, the highly reactive monohydride $\mathbf{1 2}$ is expected to be formed more readily, ${ }^{22}$ which reacts in the absence of substrate with the excess of isopropoxide to give 10. In the catalytic cycle the formation of the monohydride $\mathbf{D}$ is faster as well when $\mathbf{6}$ is used as catalyst precursor.

Several other factors than electronic effects may influence the rate of the fundamental steps as well as the structure of the intermediates proposed to be involved in the catalytic cycle. In the case of the slowest catalysts, the ${ }^{31} \mathrm{P}\left\{{ }^{1} \mathrm{H}\right\}$ NMR spectrum of the reaction mixture after consumption of the substrate showed the presence of oxidized free ligand, indicating that in 
the course of the reaction catalyst decomposition occurred. In addition, after each catalytic run, poorly soluble, light brown ruthenium-containing deposits were recovered from the reaction mixture. Infrared and ${ }^{13} \mathrm{C}$ NMR spectra of these residues pointed to the presence of carbonyl complexes, which apparently were formed during the reaction. Ozerov reported that reaction of $\left[\mathrm{RuCl}_{2}(\mathrm{PNP})\right]$ with $\mathrm{NaOH}$ in 2-propanol resulted in the formation of $[\mathrm{RuH}(\mathrm{PNP})(\mathrm{CO})]$, which is inactive in hydrogen transfer reactions. ${ }^{24}$ In addition, the ${ }^{31} \mathrm{P}\left\{{ }^{1} \mathrm{H}\right\}$ NMR spectra of the deposits revealed that oxidized ligands are also present, while ESI-MS experiments also showed that during the pretreatment time the $\mathrm{P}$ atoms of the PCP-pincer ligand are oxidized. The high catalytic activity obtained with $\mathbf{9}$, together with ESI-MS results, indicates that the introduction of electron-withdrawing substituents at the phosphorus atoms of the $\mathrm{Ru}-\mathrm{PCP}-$ diphenylphosphine manifold may decrease their susceptibility toward oxidative degradation by a stronger coordination of the PCP-pincer ligand to the metal center.

\section{Conclusions}

In this work, novel PCP-pincer $\mathrm{Ru}(\mathrm{II})$ complexes were synthesized, and their catalytic activity in the hydrogen transfer of cyclohexanone in a 2-propanol/ $\mathrm{NaOH}$ mixture was studied. It was shown that the complexes $\left[\mathrm{RuCl}\left\{\mathrm{C}_{6} \mathrm{H}_{3}\left(\mathrm{CH}_{2} \mathrm{P}\left(p-\mathrm{XC}_{6} \mathrm{H}_{4}\right)_{2}\right)_{2}-\right.\right.$ $\left.2,6\}\left(\mathrm{PPh}_{3}\right)\right]\left(\mathrm{X}=\mathrm{H}, \mathrm{OMe}, \mathrm{CF}_{3}\right)$ can be efficiently employed as catalyst precursors and that higher reaction rates are obtained in the presence of an excess of base at reflux temperature. Our experimental data showed that the initial rate of the reaction increases when electron-withdrawing $\mathrm{CF}_{3}$ groups replace the para phenyl hydrogens in the pincer ligand $\left[\mathrm{C}_{6} \mathrm{H}_{3}\left(\mathrm{CH}_{2} \mathrm{P}(p\right.\right.$ $\left.\left.\left.\mathrm{XC}_{6} \mathrm{H}_{4}\right)_{2}\right)_{2}-1,3\right]^{-}$. More importantly, in this case the duration of the pretreatment time (refluxing in 2-propanol with base) was not critical to activity. Thus, the origin of the higher initial rate may be related to the faster formation of catalytically active species.

An induction period followed by a significantly lower activity have been obtained applying the precursor $\left[\mathrm{RuCl}\left(\mathrm{PCP}^{\mathrm{F} 20}\right)\right.$ $\left.\left(\mathrm{PPh}_{3}\right)\right]$, which possesses different structural features due in part to the considerable steric effects exerted by the bulky $\mathrm{P}\left(\mathrm{C}_{6} \mathrm{~F}_{5}\right)$ rings on the ruthenium center. These findings clearly show that the steric effects can be at least as important as electronic effects and, as observed in many cases, can dominate the formation of catalytically active species.

The results of stoichiometric reactions, NMR experiments, and ESI-MS measurements provide support to the formation of the Ru-hydride-alkoxide complex $\mathrm{Na}\left[\mathrm{Ru}(\mathrm{H})\left(\mathrm{PCP}^{i \mathrm{Pr}}\right)(\mathrm{O} i \mathrm{Pr})\right.$ $\left.\left(\mathrm{PPh}_{3}\right)\right]$ during the pretreatment time. The concentration of this species is strongly dependent on the amount of base and temperature. Therefore, upon changing the experimental conditions, different PCP-pincer $\mathrm{Ru}(\mathrm{II})$ species may be present simultaneously. The fact that a higher rate is obtained when the $\mathrm{Na}\left[\mathrm{Ru}(\mathrm{H})\left(\mathrm{PCP}{ }^{i \mathrm{Pr}}\right)(\mathrm{O} i \mathrm{Pr})\left(\mathrm{PPh}_{3}\right)\right]$ species is quantitatively formed is indicative that the latter may be regarded as the active species or as a stabilizing reservoir for the active species.

The results of this work are a worthwhile subject for further studies devoted to the isolation of robust $\mathrm{PCP}-\mathrm{Ru}$ hydride species and their application in homogeneous (a)symmetric hydrogen transfer reaction of ketones.

\section{Experimental Section}

General Procedures. All reactions were performed under an atmosphere of dry, oxygen-free nitrogen using Schlenk techniques

(24) Çelenligil-Çetin, R.; Watson, L. A.; Guo, C.; Foxman, B. M.; Ozerov, O. V. Organometallics 2005, 24, 186. or in a nitrogen-filled MBraun 150 G1 glovebox. Pentane and toluene were dried over $\mathrm{Na}$ sand, THF and diethyl ether were dried over $\mathrm{Na}$ /benzophenone, and $\mathrm{CH}_{3} \mathrm{CN}$ was dried over $\mathrm{CaH}_{2}$. All solvents were freshly distilled under nitrogen prior to use. $\mathrm{CD}_{2} \mathrm{Cl}_{2}$ was purchased from Cambridge Isotope Laboratories, dried over $\mathrm{CaH}_{2}$, stored in a Schlenk flask over $4 \AA$ molecular sieves under nitrogen, and distilled prior to use. 1D NMR spectra $\left[{ }^{1} \mathrm{H}(300.1\right.$ $\mathrm{MHz}),{ }^{13} \mathrm{C}(75.5 \mathrm{MHz}),{ }^{19} \mathrm{~F}(282.4 \mathrm{MHz})$, and ${ }^{31} \mathrm{P}\left\{{ }^{1} \mathrm{H}\right\}(121.4$ $\mathrm{MHz})$ ] were recorded on a Varian Inova $300 \mathrm{MHz}$ spectrometer. Chemical shift values are reported in $\operatorname{ppm}(\delta)$ and referenced internally to residual solvent signals $\left({ }^{1} \mathrm{H},{ }^{13} \mathrm{C}\right)$ or externally $\left({ }^{19} \mathrm{~F}\right.$, $\mathrm{C}_{6} \mathrm{~F}_{6}, \delta=-164.9 ;{ }^{31} \mathrm{P}, \mathrm{H}_{3} \mathrm{PO}_{4}$ in $\left.\mathrm{D}_{2} \mathrm{O}, \delta=0\right)$ ). All reagents were purchased from Acros Chemicals and used as received. Complexes $\left[\mathrm{RuCl}\left\{\mathrm{C}_{6} \mathrm{H}_{3}\left(\mathrm{CH}_{2} \mathrm{NMe}_{2}\right)_{2}-2,6\right\}\left(\mathrm{PPh}_{3}\right)\right],{ }^{16} \mathbf{8 a},{ }^{9}$ and $\mathbf{9}^{15 \mathrm{c}}$ and the ligands $\left(p-\mathrm{MeOC}_{6} \mathrm{H}_{4}\right) \mathrm{PCl}^{12},\left(p-\mathrm{CF}_{3} \mathrm{C}_{6} \mathrm{H}_{4}\right) \mathrm{PCl},{ }^{13}$ and $7^{10}$ were synthesized via literature procedures. Elemental analyses were performed by Dornis und Kolbe, Mikroanalytisches Laboratorium, Müllheim a.d. Ruhr, Germany. High-resolution electrospray ionization (ESI) mass spectra were recorded with a Micromass LC-TOF mass spectrometer of the Department of Chemistry, Biomolecular Mass Spectrometry, Utrecht University. The electrospray ionization mass spectrometry (ES-MS) experiments were conducted on an API III (PE SCIEX) triple quadrupole MS system with an IonSpray (pneumatically assisted electrospray) source equipped with a gas curtain, which are contained in a closed chamber that can be evacuated, flushed, and maintained under nitrogen. Typical sample analysis: in a glovebox, a sample of the catalyst, 2-propanol, and $\mathrm{NaOH}$ were taken up into a $500 \mu \mathrm{L}$ syringe (Model 1750 RNR, Hamilton) and electrosprayed via a syringe pump operating at 10 $\mu \mathrm{L} / \mathrm{min}$. The capillary voltage was $3.5 \mathrm{kV}$. Mass spectra were recorded from $\mathrm{m} / \mathrm{z} 50$ to 900 at $10 \mathrm{~s}$ per scan using a step size of $0.1 \mathrm{Da}$. The sampling orifice (nozzle) was at $+70 \mathrm{~V}$. The skimmer located behind the sampling orifice was at $+25 \mathrm{~V}$ in all experiments.

$\left[\mathrm{C}_{6} \mathrm{H}_{4}\left\{\mathrm{CH}_{2} \mathrm{P}\left(p-\mathrm{MeOC}_{6} \mathrm{H}_{4}\right)_{2}\right\}_{2}-\mathbf{1 , 3}\right]$ (PCPOMe) (3). An excess of $\mathrm{Mg}$ turnings $(0.48 \mathrm{~g}, 20 \mathrm{mmol})$ was stirred in dry THF $(50 \mathrm{~mL})$ in a round-bottom flask equipped with a pressure-equalizing dropping funnel, a sintered glass frit, and a nitrogen inlet for $1 \mathrm{~h}$. To this was added $\mathrm{BrCH}_{2} \mathrm{CH}_{2} \mathrm{Br}(0.2 \mathrm{~mL}, 2.0 \mathrm{mmol})$, and the flask was heated to reflux for $1 \mathrm{~min}$. After cooling for $5 \mathrm{~min}$, the THF was removed in vacuo and fresh THF $(100 \mathrm{~mL})$ was added. In a separate Schlenk flask, $\alpha, \alpha^{\prime}$-dichloro-meta-xylene (1.21 g, $\left.7.0 \mathrm{mmol}\right)$ was dissolved in dry THF $(200 \mathrm{~mL})$, transferred via cannula to the dropping funnel, and added dropwise at room temperature over 1 $\mathrm{h}$ to the Mg turnings. On addition, the solution became light green. After the addition was complete, the reaction was stirred overnight at room temperature. The green solution was filtered to remove the excess $\mathrm{Mg}$ and subsequently cooled to $-78^{\circ} \mathrm{C}$. $\left(p-\mathrm{MeOC}_{6} \mathrm{H}_{4}\right)_{2}-$ $\mathrm{PCl}(3.9 \mathrm{~g}, 14.0 \mathrm{mmol})$ in dry THF $(100 \mathrm{~mL})$ was added slowly via cannula. The yellow-green color of the bis-Grignard reagent dissipated at the end of the addition. The reaction was stirred at $-78^{\circ} \mathrm{C}$ for $5 \mathrm{~min}$ and warmed to room temperature overnight. All volatiles were removed in vacuo, and fresh pentane $(30 \mathrm{~mL})$ was added. The mixture was stirred for $30 \mathrm{~min}$, and all volatiles were removed in vacuo. A fresh portion of pentane $(200 \mathrm{~mL})$ was added, and the reaction mixture was filtered. The white magnesium salts were washed with dry pentane $(3 \times 50 \mathrm{~mL})$, and the filtrate was pumped dry to obtain a white, thick oil. Yield: $7.3 \mathrm{~g}, 88 \%$. Characterization was performed with the borane-protected form of 3, $\left[\mathrm{C}_{6} \mathrm{H}_{4}\left\{\mathrm{CH}_{2} \mathrm{P}\left(p-\mathrm{MeOC}_{6} \mathrm{H}_{4}\right)\left(\mathrm{BH}_{3}\right)\right\}_{2}-2,6\right]$ (3b), prepared by applying the following synthetic procedure: to a solution of $\mathbf{3}(0.21$ $\mathrm{g}, 0.35 \mathrm{mmol})$ in $\mathrm{CH}_{2} \mathrm{Cl}_{2}(30 \mathrm{~mL})$ was added $\mathrm{BH}_{3} \cdot \mathrm{SMe}_{2}(0.054 \mathrm{~g}$, $0.71 \mathrm{mmol}$ ) at room temperature. The mixture was stirred at room temperature for $10 \mathrm{~h}$. All volatiles were evaporated and the white sticky solid washed with hot EtOH and dried in vacuo to give $\mathbf{3 b}$ as a white air-stable powder. Yield: $0.10 \mathrm{~g}, 47 \% .{ }^{1} \mathrm{H}$ NMR $(300.1$ $\left.\mathrm{MHz}, \mathrm{CD}_{2} \mathrm{Cl}_{2}\right): \delta 7.51\left(\mathrm{t},{ }^{2} J_{\mathrm{HH}}=9 \mathrm{~Hz}, 8 \mathrm{H}\right.$, ortho-H $\left.\mathrm{ArOCH}_{3}\right)$, $6.95\left(\mathrm{~d},{ }^{2} J_{\mathrm{HH}}=9 \mathrm{~Hz}, 8 \mathrm{H}, \text { meta }-\mathrm{H} \mathrm{ArOCH}\right)_{3}, 6.87(\mathrm{~d}, 1 \mathrm{H}, \mathrm{H}-\mathrm{C}(5))$, 
$6.77(\mathrm{~m}, 2 \mathrm{H}, \mathrm{H}-\mathrm{C}(4,6)), 6.67(\mathrm{~s}, 1 \mathrm{H}, \mathrm{H}-\mathrm{C}(2)), 3.84(\mathrm{~s}, 12 \mathrm{H}$, $\left.\mathrm{CH}_{3} \mathrm{O}\right), 3.43\left(\mathrm{~d},{ }^{2} J_{\mathrm{HH}}=12 \mathrm{~Hz}, 4 \mathrm{H}, \mathrm{CH}_{2} \mathrm{P}\right), 1.7-0.5$ (br q, $6 \mathrm{H}$, $\left.\mathrm{BH}_{3}\right) .{ }^{13} \mathrm{C} \mathrm{NMR}\left(75.5 \mathrm{MHz}, \mathrm{CD}_{2} \mathrm{Cl}_{2}\right.$ ): $\delta 162.3$ (s, para-C ArOCH 3 ), 134.4-114.4 (Ar), $57.0\left(\mathrm{~s}, \mathrm{CH}_{3} \mathrm{O}\right), 34.5\left(\mathrm{~d},{ }^{1} J_{\mathrm{CP}}=33 \mathrm{~Hz}, \mathrm{CH}_{2}\right)$. ${ }^{31} \mathrm{P}\left\{{ }^{1} \mathrm{H}\right\}$ NMR $\left(121.4 \mathrm{MHz}, \mathrm{CD}_{2} \mathrm{Cl}_{2}\right): \delta 16.0$ (br s). Anal. Calcd for $\mathrm{C}_{36} \mathrm{H}_{42} \mathrm{~B}_{2} \mathrm{O}_{4} \mathrm{P}_{2} \cdot 2 \mathrm{CH}_{2} \mathrm{Cl}_{2}$ : C, 57.62; H, 5.85; $\mathrm{P}, 7.92$. Found: $\mathrm{C}$, 57.62; H, 5.43; P, 7.72 .

$\left[\mathrm{C}_{6} \mathrm{H}_{4}\left\{\mathrm{CH}_{2} \mathrm{P}\left(p-\mathrm{CF}_{3} \mathrm{C}_{6} \mathrm{H}_{4}\right)_{2}\right\}_{2}-\mathbf{1}, 3\right]\left(\mathrm{PCP}^{\mathrm{CF}}\right)$ (4). Ligand 4 was prepared by applying the synthetic procedure described for ligand 4 employing $0.33 \mathrm{~g}(0.14 \mathrm{mmol})$ of $\mathrm{Mg}, 0.87 \mathrm{~g}$ of $\alpha, \alpha^{\prime}$-dichlorometa-xylene $(5.0 \mathrm{mmol})$, and $4.0 \mathrm{~g}$ of $\left(p-\mathrm{CF}_{3} \mathrm{C}_{6} \mathrm{H}_{4}\right)_{2} \mathrm{PCl}(10.0$ mmol). Yield: $3.5 \mathrm{~g}, 95 \%$. Characterization was performed with the borane-protected form of $4\left(\left[\mathrm{C}_{6} \mathrm{H}_{4}\left\{\mathrm{CH}_{2} \mathrm{P}\left(p-\mathrm{CF}_{3} \mathrm{C}_{6} \mathrm{H}_{4}\right)\left(\mathrm{BH}_{3}\right)\right\}_{2^{-}}\right.\right.$ 2,6] (4b)) prepared by adding $\mathrm{BH}_{3} \cdot \mathrm{SMe}_{2}(0.10 \mathrm{~g}, 1.3 \mathrm{mmol})$ to a solution of $4(0.5 \mathrm{~g} ; 0.67 \mathrm{mmol})$ in $\mathrm{CH}_{2} \mathrm{Cl}_{2}(30 \mathrm{~mL})$ at room temperature. The mixture was stirred for $10 \mathrm{~h}$ and, subsequently, all volatiles were evaporated, yielding $\mathbf{4 b}$ as a white, air-stable solid. The solid was further purified by column chromatography on silica gel (hexane $/ \mathrm{CH}_{2} \mathrm{Cl}_{2}, 3: 1 \mathrm{v} / \mathrm{v}$ ), yielding a white solid. Yield: 0.29 g, 56\%. ${ }^{1} \mathrm{H}$ NMR $\left(300.1 \mathrm{MHz}, \mathrm{CD}_{2} \mathrm{Cl}_{2}\right): \delta 7.92-7.62(\mathrm{~m}, 16 \mathrm{H}$, $\mathrm{ArH}), 6.99$ (s, 1H, H-C(2)), $6.79(\mathrm{~m}, 3 \mathrm{H}, \mathrm{H}-\mathrm{C}(5)$ and $\mathrm{H}-\mathrm{C}(6))$, $3.63\left(\mathrm{~d},{ }^{2} J_{\mathrm{HH}}=18 \mathrm{~Hz}, 4 \mathrm{H}, \mathrm{CH}_{2} \mathrm{P}\right), 1.28-0.2\left(\right.$ br q, $\left.6 \mathrm{H}, \mathrm{BH}_{3}\right) .{ }^{13} \mathrm{C}$ NMR (75.5 MHz, $\left.\mathrm{CD}_{2} \mathrm{Cl}_{2}\right): \delta 133.8-122.0(\mathrm{Ar}), 34.5\left(\mathrm{~d},{ }^{1} J_{\mathrm{CP}}=\right.$ $\left.31 \mathrm{~Hz}, \mathrm{CH}_{2}\right) .{ }^{31} \mathrm{P}\left\{{ }^{1} \mathrm{H}\right\} \mathrm{NMR}\left(121.4 \mathrm{MHz}, \mathrm{CD}_{2} \mathrm{Cl}_{2}\right): \delta 20.9$ (br s). ${ }^{19} \mathrm{~F}\left\{{ }^{1} \mathrm{H}\right\}$ NMR $\left(282.4 \mathrm{MHz}, \mathrm{CD}_{2} \mathrm{Cl}_{2}\right): \delta-64.97\left(\mathrm{~s}, \mathrm{CF}_{3}\right)$. Anal. Calcd for $\mathrm{C}_{36} \mathrm{H}_{30} \mathrm{~B}_{2} \mathrm{~F}_{12} \mathrm{P}_{2}$ : C, 55.85; H, 3.91; P, 8.00. Found: C, 56.05; H, 3.98; P, 7.96.

[RuCl(PCPOMe $\left.)\left(\mathbf{P P h}_{3}\right)\right]$ (5). Ligand $3(0.27 \mathrm{~g}, 0.4 \mathrm{mmol})$ was dissolved in dry benzene $(10 \mathrm{~mL})$ and transferred, at room temperature, into a Schlenk flask containing complex [RuCl$\left.\left\{\mathrm{C}_{6} \mathrm{H}_{3}\left(\mathrm{CH}_{2} \mathrm{NMe}_{2}\right)_{2}-2,6\right\}\left(\mathrm{PPh}_{3}\right)\right](0.27 \mathrm{~g}, 0.4 \mathrm{mmol})$ in $10 \mathrm{~mL}$ of dry benzene. The purple reaction mixture turned to deep green after $5 \mathrm{~h}$ of heating. After $48 \mathrm{~h}$ of heating under reflux, the solvent was removed in vacuo. The obtained green residue was washed with cold hexane and dissolved in ether. The ether layer was filtered through a sintered-glass filter, and subsequently, the solvent was dried in vacuo, yielding $\mathbf{5}$ as a green, air/moisture-sensitive solid. Yield: $0.27 \mathrm{~g}, 60 \%$. No further purification by crystallization of the compound was possible due to its high solubility in all common organic solvents. ${ }^{1} \mathrm{H}$ NMR $\left(300.1 \mathrm{MHz}, \mathrm{CD}_{2} \mathrm{Cl}_{2}\right.$ ): $\delta$ 7.81-6.46 (m, 34H, ArH), 3.85 (s, 6H, $\left.\mathrm{CH}_{3} \mathrm{O}\right), 3.65$ (s, 6H, $\left.\mathrm{CH}_{3} \mathrm{O}\right), 3.42$ (dvt, $\left.{ }_{2} J_{\mathrm{HH}}=16 \mathrm{~Hz},{ }^{2} J_{\mathrm{HP}}=6 \mathrm{~Hz}, 2 \mathrm{H}, \mathrm{CH}_{2} \mathrm{P}\right), 2.31\left(\mathrm{bd},{ }^{2} J_{\mathrm{HH}}=16 \mathrm{~Hz}\right.$, $\left.2 \mathrm{H}, \mathrm{CH}_{2} \mathrm{P}\right) .{ }^{13} \mathrm{C}$ NMR $\left(75.5 \mathrm{MHz}, \mathrm{CD}_{2} \mathrm{Cl}_{2}\right): \delta 173.0\left(\mathrm{~d},{ }^{2} J_{\mathrm{CP}}=14\right.$ $\left.\mathrm{Hz}, \mathrm{C}_{\mathrm{ipso}}\right), 151.2\left(\mathrm{t},{ }^{2} J_{\mathrm{CP}}=8 \mathrm{~Hz}, \mathrm{C}-2,6\right), 136.7\left(\mathrm{dvt},{ }^{1} J_{\mathrm{CC}}=50 \mathrm{~Hz}\right.$, $\left.{ }^{1} J_{\mathrm{CP}}=2-3 \mathrm{~Hz}, \mathrm{C}_{\text {quat. }} \mathrm{PPh}_{3}\right), 134.3-126.0(\mathrm{C} \mathrm{Ar}), 122.9$ (vt, C-3,5), 121.7 (s, C-4), 55.5 (s, $\left.\mathrm{CH}_{3} \mathrm{O}\right), 39.3\left(\mathrm{vt},{ }^{1} J_{\mathrm{CP}}=16 \mathrm{~Hz}, \mathrm{CH}_{2} \mathrm{P}\right)$. ${ }^{31} \mathrm{P}\left\{{ }^{1} \mathrm{H}\right\} \mathrm{NMR}\left(121.4 \mathrm{MHz}, \mathrm{CD}_{2} \mathrm{Cl}_{2}\right): \delta 82.7\left(\mathrm{t},{ }^{2} J_{\mathrm{PP}}=31.5 \mathrm{~Hz}\right)$, $35.2\left(\mathrm{~d},{ }^{2} J_{\mathrm{PP}}=31.5 \mathrm{~Hz}\right)$. ESI-MS: $\mathrm{m} / \mathrm{z}, 957\left([\mathrm{M}-\mathrm{Cl}]^{+}, 100 \%\right)$.

$\left[\mathbf{R u C l}\left(\mathbf{P C P} \mathbf{P F}^{\mathbf{3}}\right)\left(\mathbf{P P h}_{3}\right)\right](\mathbf{6})$. The reaction mixture obtained by adding ligand $4(0.8 \mathrm{~g}, 1.1 \mathrm{mmol})$ in dry benzene $(10 \mathrm{~mL})$ and complex $\left[\mathrm{RuCl}\left\{\mathrm{C}_{6} \mathrm{H}_{3}\left(\mathrm{CH}_{2} \mathrm{NMe}_{2}\right)_{2}-2,6\right\}\left(\mathrm{PPh}_{3}\right)\right](0.7 \mathrm{~g}, 1.1 \mathrm{mmol})$ in dry benzene $(20 \mathrm{~mL})$ was stirred at reflux temperature for $48 \mathrm{~h}$. The color of the mixture turned to deep green upon heating. The solvent was evaporated, and the green residue obtained was washed with cold hexane. $\mathbf{6}$ was then extracted with ether. The ether layer was filtered through a glass filter and the solvent removed in vacuo to give $\mathbf{6}$ as an air/moisture-sensitive, green solid. No further purification of the compound by crystallization was possible due to its high solubility in all common organic solvents. Yield: 0.63 g, 46\%. ${ }^{1} \mathrm{H}$ NMR $\left(300.1 \mathrm{MHz}, \mathrm{CD}_{2} \mathrm{Cl}_{2}\right): \delta 8.04-7.04(\mathrm{~m}, 26 \mathrm{H}$, Ar), $6.90\left(\mathrm{~m}, 6 \mathrm{H}\right.$, meta- $\mathrm{H} \mathrm{PPh}$ ), $3.58\left(\mathrm{dvt},{ }^{2} J_{\mathrm{HH}}=16 \mathrm{~Hz},{ }^{2} J_{\mathrm{HP}}=\right.$ $\left.6 \mathrm{~Hz}, 2 \mathrm{H}, \mathrm{CH}_{2} \mathrm{P}\right), 2.50\left(\mathrm{bd},{ }^{2} J_{\mathrm{HH}}=16 \mathrm{~Hz}, 2 \mathrm{H}, \mathrm{CH}_{2} \mathrm{P}\right) .{ }^{13} \mathrm{C} \mathrm{NMR}$ $\left(75.5 \mathrm{MHz}, \mathrm{CD}_{2} \mathrm{Cl}_{2}\right): \delta 170.3\left(\mathrm{~d},{ }^{2} J_{\mathrm{CP}}=14 \mathrm{~Hz}, \mathrm{C}_{\mathrm{ipso}}\right), 150.2(\mathrm{vt}$, C-2,6), 138.9-124.9 (C Ar), 123.7 (m, C-3,5), 122.7 (s, C-4), 38.7 $\left(\mathrm{vt},{ }^{1} J_{\mathrm{CP}}=16 \mathrm{~Hz}, \mathrm{CH}_{2} \mathrm{P}\right) .{ }^{31} \mathrm{P}\left\{{ }^{1} \mathrm{H}\right\} \mathrm{NMR}\left(121.4 \mathrm{MHz}, \mathrm{CD}_{2} \mathrm{Cl}_{2}\right): \delta$ $76.1\left(\mathrm{t},{ }^{2} J_{\mathrm{PP}}=31.5 \mathrm{~Hz}\right), 36.4\left(\mathrm{~d},{ }^{2} J_{\mathrm{PP}}=31.5 \mathrm{~Hz}\right) .{ }^{19} \mathrm{~F}\left\{{ }^{1} \mathrm{H}\right\} \mathrm{NMR}$ $\left(282.4 \mathrm{MHz}, \mathrm{CD}_{2} \mathrm{Cl}_{2}\right): \delta-65.09\left(\mathrm{~s}, \mathrm{CF}_{3}\right),-65.53\left(\mathrm{~s}, \mathrm{CF}_{3}\right)$. ESI-
MS: $m / z 1143.9\left([\mathrm{M}+\mathrm{H}]^{+}, 60 \%\right), 1108.8\left([\mathrm{M}-\mathrm{Cl}]^{+}, 100 \%\right)$, $881.6\left(\left[\mathrm{M}-\mathrm{PPh}_{3}\right]^{+}, 100 \%\right), 845.7\left(\left[\mathrm{M}-\mathrm{Cl}-\mathrm{PPh}_{3}\right]^{+}, 100 \%\right)$.

[Ru(PCP $\left.\left.\mathbf{P C}^{\mathbf{F} 0}\right)\left(\mathbf{P P h}_{3}\right)\right](\mathbf{O T f})(\mathbf{8 b}) . \operatorname{AgOTf}(0.028 \mathrm{~g}, 0.1 \mathrm{mmol})$ in $\mathrm{CH}_{2} \mathrm{Cl}_{2}(5 \mathrm{~mL})$ was added to a solution of $8 \mathbf{a}(0.14 \mathrm{~g}, 0.1 \mathrm{mmol})$ in $\mathrm{CH}_{2} \mathrm{Cl}_{2}(10 \mathrm{~mL})$. A color change of the reaction mixture from red to purple was observed. After stirring at room temperature for $5 \mathrm{~h}$, the purple solution was separated by filtration over Celite from the $\mathrm{AgCl}$ formed. Removal of the solvent in vacuo gave $\mathbf{8 b}$ as an air/moisture-stable, purple solid. Yield: $0.12 \mathrm{~g}, 89 \% .{ }^{1} \mathrm{H}$ NMR $\left(300.1 \mathrm{MHz}, \mathrm{CD}_{2} \mathrm{Cl}_{2}\right): \delta 7.34(\mathrm{~m}, 3 \mathrm{H}, \text { para }-\mathrm{H} \mathrm{PPh})_{3}, 7.16(\mathrm{~m}, 12 \mathrm{H}$, ortho- and meta- $\left.\mathrm{H} \mathrm{PPh}_{3}\right), 7.06\left(\mathrm{~d},{ }^{3} J_{\mathrm{HH}}=7.5 \mathrm{~Hz}, 2 \mathrm{H}, \mathrm{Ar}\right), 6.98(\mathrm{t}$, $\left.{ }^{3} J_{\mathrm{HH}}=7.0 \mathrm{~Hz}, 1 \mathrm{H}, \mathrm{Ar}\right), 4.14\left(\mathrm{~m}, 2 \mathrm{H}, \mathrm{CH}_{2}\right), 3.07\left(\mathrm{bd},{ }^{2} J_{\mathrm{HH}}=18.6\right.$ $\left.\mathrm{Hz}, 2 \mathrm{H}, \mathrm{CH}_{2}\right) .{ }^{13} \mathrm{C} \mathrm{NMR}\left(74.4 \mathrm{MHz}, \mathrm{CD}_{2} \mathrm{Cl}_{2}\right): \delta 156.1\left(\mathrm{C}_{\mathrm{ipso}}\right)$, 149.9 (t, Ar), 147.7 (doublet of multiplet, ${ }^{1} J_{\mathrm{CF}}=211.5 \mathrm{~Hz}, \mathrm{ArF}$ ), 143.9 (doublet of multiplet, ${ }^{1} J_{\mathrm{CF}}=283.5 \mathrm{~Hz}, \mathrm{ArF}$ ), 137.7 (doublet of multiplet, $\left.{ }^{1} J_{\mathrm{CF}}=258.9 \mathrm{~Hz}, \mathrm{ArF}\right), 134.8-104.72(\mathrm{C} \mathrm{Ar}), 40.33$ $\left(\mathrm{m}, \mathrm{CH}_{2}\right) .{ }^{31} \mathrm{P}\left\{{ }^{1} \mathrm{H}\right\} \mathrm{NMR}\left(121.4 \mathrm{MHz}, \mathrm{CD}_{2} \mathrm{Cl}_{2}\right): \delta 55.6(\mathrm{br} \mathrm{m}$, $\left.\mathrm{PPh}_{3}\right), 25.8\left(\mathrm{~d},{ }^{2} J_{\mathrm{PP}}=35.0 \mathrm{~Hz}, \mathrm{P}-\mathrm{ArF}\right) .{ }^{19} \mathrm{~F}\left\{{ }^{1} \mathrm{H}\right\} \mathrm{NMR}(282.4 \mathrm{MHz}$, $\mathrm{CD}_{2} \mathrm{Cl}_{2}, \mathrm{RT}$ ): $\delta-80.47$ (s, OTf), -125.23 (br s, 4F, ortho-F ArF), -137.03 (br s, 4F, ortho-F ArF), -148.83 (br s, 2F, para-F ArF), -149.77 (br s, 2F, para-F ArF), -161.72 (br s, 4F, meta-F ArF), -162.15 (br s, 4F, meta-F ArF). IR: $v_{\text {as }}=1293.53$ and 1261.06 $\mathrm{cm}^{-1} ; v_{\mathrm{as}}=1231.39$ and $1211.23 \mathrm{~cm}^{-1}\left(\mathrm{CF}_{3}\right) ; v_{\mathrm{as}}=1168.06$ and $1088.86 \mathrm{~cm}^{-1}\left(\mathrm{CF}_{3}\right) ; v_{\text {as }}=1022.49 \mathrm{~cm}^{-1}\left(\mathrm{SO}_{3}\right)$. Anal. Calcd for $\mathrm{C}_{51} \mathrm{H}_{22} \mathrm{~F}_{23} \mathrm{P}_{3} \mathrm{RuO}_{4} \mathrm{~S}$ : C, 45.52; $\mathrm{H}, 1.65 ; \mathrm{P}, 6.90$. Found: C, 45.33; H, 1.74; P, 6.73. ESI-MS: $m / z 1196.9$ ([M] $\left.]^{+}, 100\right)$.

$\left[\mathbf{R u H}\left(\mathbf{P C P}{ }^{i \mathbf{P r}}\right)(\mathbf{O i P r})\left(\mathbf{P P h}_{3}\right)\right] \mathbf{N a}(\mathbf{1 0})$. Complex 9 (0.11 g, 0.16 mmol) was mixed with an excess of $\mathrm{NaO} i \operatorname{Pr}(0.13 \mathrm{~g}, 1.6 \mathrm{mmol})$ in toluene $(15 \mathrm{~mL})$. The reaction mixture, the color of which turned instantaneously from green to yellow upon heating, was stirred at reflux temperature for $1 \mathrm{~h}$. The solvent was concentrated in vacuo. Slow diffusion of pentane caused the precipitation of complex $\mathbf{1 0}$ as a pale yellow solid. Unfortunately, due to the concomitant precipitation of $\mathrm{NaO} i \mathrm{Pr}$, which could not be separated, elemental analysis of $\mathbf{1 0}$ did not provide correct values for the complete characterization. However, the structure of $\mathbf{1 0}$ in solution can be readily assigned on the basis of NMR techniques. ${ }^{1} \mathrm{H}$ NMR (300.1 $\left.\mathrm{MHz}, \mathrm{C}_{6} \mathrm{D}_{6}\right): \delta 7.45\left(\mathrm{~m}, 6 \mathrm{H}\right.$, ortho- $\left.\mathrm{H} \mathrm{PPh}_{3}\right), 7.10(\mathrm{~m}, 3 \mathrm{H}$, para $-\mathrm{H}$, $\mathrm{PPh}_{3}$ ), 7.04 (m, 3H, Ar), 6.92 (m, 6H, meta-H, $\mathrm{PPh}_{3}$ ), 4.23 (br sep, $\mathrm{CH}-\mathrm{O}$, exc. $\mathrm{NaO} i \mathrm{Pr}$ ), 3.83 (br s, $1 \mathrm{H}, \mathrm{CH}-\mathrm{O}$ ), 2.91 (dvt, ${ }^{2} J_{\mathrm{HH}}=$ $\left.16 \mathrm{~Hz},{ }^{2} J_{\mathrm{HP}}=5 \mathrm{~Hz}, 2 \mathrm{H}, \mathrm{CH}_{2} \mathrm{P}\right), 2.31\left(\mathrm{dvt},{ }^{2} J_{\mathrm{HH}}=16 \mathrm{~Hz}, 2 \mathrm{H}\right.$, $\left.\mathrm{CH}_{2} \mathrm{P}\right), 1.96(\mathrm{~m}, 4 \mathrm{H}, \mathrm{CH}), 1.30\left(\mathrm{~d},{ }^{2} J_{\mathrm{HH}}=5.4 \mathrm{~Hz}, \mathrm{CH}_{3}\right.$, exc. $\mathrm{NaO} i \mathrm{Pr}), 0.83\left(\mathrm{dd},{ }^{3} J_{\mathrm{HH}}=6.8 \mathrm{~Hz},{ }^{3} J_{\mathrm{HP}}=13.7 \mathrm{~Hz}, 12 \mathrm{H}, \mathrm{CH}_{3}\right.$ ), $0.72\left(\mathrm{dd},{ }^{3} J_{\mathrm{HH}}=6.0 \mathrm{~Hz},{ }^{3} J_{\mathrm{HP}}=11.1 \mathrm{~Hz}, 12 \mathrm{H}, \mathrm{CH}_{3}\right),-9.17(\mathrm{dt}$, ${ }^{2} J_{\mathrm{HH}}=20.0$ and $\left.{ }^{2} J_{\mathrm{HP}}=82.2 \mathrm{~Hz}, 1 \mathrm{H}, \mathrm{Ru}-\mathrm{H}\right) .{ }^{13} \mathrm{C} \mathrm{NMR}(75.5$ $\left.\mathrm{MHz}, \mathrm{C}_{6} \mathrm{D}_{6}\right): \delta 177.9\left(\mathrm{t},{ }^{2} J_{\mathrm{CP}}=5 \mathrm{~Hz}, \mathrm{C}_{\mathrm{ipso}}\right), 149.2\left(\mathrm{t},{ }^{2} J_{\mathrm{CP}}=9\right.$ $\mathrm{Hz}, \mathrm{C}-2,6), 140.8\left(\mathrm{~d},{ }^{2} J_{\mathrm{CP}}=25 \mathrm{~Hz}, \mathrm{C}_{\text {quat. }} \mathrm{PPh}_{3}\right), 134.17-127.43$ (ortho, meta, and para-C $\mathrm{PPh}_{3}$ ), 122.7 (s, C-4), 120.5 (vt, C-3,5), 62.6 (br s, $\mathrm{CH}-\mathrm{O}$, exc. $\mathrm{NaO} i \mathrm{Pr}$ ), 59.0 (br m O-CH), 44.4 (vt, ${ }^{1} J_{\mathrm{CP}}=13 \mathrm{~Hz}, \mathrm{CH}_{2} \mathrm{P}$ ), 29.8 (br s, $\mathrm{CH}_{3}$, exc. $\mathrm{NaO} i \mathrm{Pr}$ ), 29.0 (vt, ${ }^{4} J_{\mathrm{CP}}$ $\left.=8.8 \mathrm{~Hz}, \mathrm{CH}_{3}\right), 26.0($ br s, $\mathrm{CH}), 22.6,20.9,18.6,16.7\left(\mathrm{~s}\right.$, all $\left.\mathrm{CH}_{3}\right)$. ${ }^{31} \mathrm{P}\left\{{ }^{1} \mathrm{H}\right\} \mathrm{NMR}\left(121.4 \mathrm{MHz}, \mathrm{C}_{6} \mathrm{D}_{6}\right): \delta 72.1\left(\mathrm{~d},{ }^{2} J_{\mathrm{PP}}=15.5 \mathrm{~Hz}\right)$, $35.8\left(\mathrm{t},{ }^{2} J_{\mathrm{PP}}=15.5 \mathrm{~Hz}\right)$

Procedure for the Hydrogen Transfer Reaction. In a typical experiment performed under a $\mathrm{N}_{2}$ atmosphere, the ruthenium complex $(0.02 \mathrm{mmol})$ was mixed with $\mathrm{NaOH}(0.4 \mathrm{mmol})$ in 2-propanol $(5 \mathrm{~mL})$ into a two-neck round-bottom flask equipped with a reflux condenser and a septum. Next, the flask was lowered into a preheated oil bath of $82{ }^{\circ} \mathrm{C}$, and the resulting mixture was heated to reflux for $1 \mathrm{~h}$. A color change was observed from green to yellow for complexes $\mathbf{5}$ and $\mathbf{6}$ and to red for $\mathbf{9}$ within a few minutes. Subsequently, cyclohexanone $(20 \mathrm{mmol})$ in 2-propanol $(10 \mathrm{~mL})$ was added by a syringe. Samples of the reaction mixture were taken by an airtight syringe. The reaction was monitored in time by gas chromatography until total conversion of the substrate was reached. The experiments performed under an Ar atmosphere were performed employing solvents and reagents degassed under 
Ar, by applying the procedure described above for the experiments carried out under $\mathrm{N}_{2}$.

Monitoring the Effect of Pretreatment Time on the Activity of $\left[\mathbf{R u C l}\left(\mathbf{P C P} \mathbf{P r}^{\mathrm{Pr}}\right)\left(\mathbf{P P h}_{3}\right)\right](\mathbf{9})$. To a solution of $\mathbf{9}(0.02 \mathrm{mmol})$ in 2-propanol ( $5 \mathrm{~mL})$ was added $\mathrm{NaOH}(0.4 \mathrm{mmol})$ in 2-propanol (10 $\mathrm{mL}$ ). The resultant mixture was heated to reflux under an $\mathrm{N}_{2}$ atmosphere. Aliquots of the solution were withdrawn by a syringe and poured into a Schlenk flask. All the volatiles were dried in vacuo, and the yellow-brown residue obtained was dissolved in dry benzene. Addition of pentane caused the precipitation of a light yellow solid, which was collected by centrifugation and dried in vacuo. Then, ${ }^{1} \mathrm{H}$ and ${ }^{31} \mathrm{P}\left\{{ }^{1} \mathrm{H}\right\}$ NMR spectra were recorded at room temperature in $\mathrm{C}_{6} \mathrm{D}_{6}$.
Acknowledgment. The authors kindly acknowledge Dr. S. Araujo Bambirra for his assistance during ESI measurements. This work was supported by the Council for Chemical Sciences from the Netherlands Organization for Scientific Research (CWNWO) and Natural Sciences and Engineering Research Council (NSERC) of Canada (P.A.C.).

Supporting Information Available: ${ }^{1} \mathrm{H},{ }^{13} \mathrm{C}$, and ${ }^{31} \mathrm{P}\left\{{ }^{1} \mathrm{H}\right\} \mathrm{NMR}$ spectra of complexes 5, 6, and 10. ESI-MS spectra of complexes 5 and $\mathbf{6}$. This material is available free of charge via the Internet at http://pubs.acs.org.

OM060874F 